\title{
In Strange Company: The Puzzle of Private Investment in State-Controlled Firms
}

\section{Citation}

Pargendler, Mariana, Aldo Musacchio, and Sergio G. Lazzarini. "In Strange Company: The Puzzle of Private Investment in State-Controlled Firms." Harvard Business School Working Paper, No. 13-071, February 2013.

\section{Permanent link}

http://nrs.harvard.edu/urn-3:HUL.InstRepos:10304547

\section{Terms of Use}

This article was downloaded from Harvard University's DASH repository, and is made available under the terms and conditions applicable to Open Access Policy Articles, as set forth at http:// nrs.harvard.edu/urn-3:HUL.InstRepos:dash.current.terms-of-use\#OAP

\section{Share Your Story}

The Harvard community has made this article openly available.

Please share how this access benefits you. Submit a story.

Accessibility 


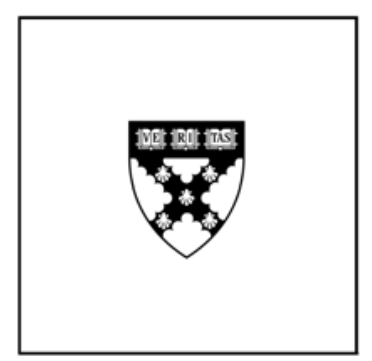

\title{
In Strange Company: The Puzzle of Private Investment in State- Controlled Firms
}

\author{
Mariana Pargendler \\ Aldo Musacchio \\ Sergio G. Lazzarini
}

\section{Working Paper}

13-071

February 14, 2013 


\title{
In Strange Company: The Puzzle of Private Investment in State-Controlled Firms
}

\author{
Mariana Pargendler \\ FGV Law School \\ Aldo Musacchio \\ Harvard Business School \\ Sergio G. Lazzarini \\ Insper Institute of Education and Research
}

February 2013

\begin{abstract}
A large legal and economic literature describes how state-owned enterprises (SOEs) suffer from a variety of agency and political problems. Less theory and evidence, however, have been generated about the reasons why state-owned enterprises listed in stock markets manage to attract investors to buy their shares (and bonds). In this Article, we examine this apparent puzzle and develop a theory of how legal and extralegal constraints allow mixed enterprises to solve some of these problems. We then use three detailed case studies of state-owned oil companies Brazil's Petrobras, Norway's Statoil, and Mexico's Pemex - to examine how our theory fares in practice. Overall, we show how mixed enterprises have made progress to solve some of their agency problems, even as government intervention persists as the biggest threat to private minority shareholders in these firms.
\end{abstract}

\footnotetext{
${ }^{*}$ We thank the useful research assistance by Claudia Bruschi, Alexandre Caraccio and Thiago Reis.
} 
No two characters seem more inconsistent than those of trader and sovereign. If the trading spirit of the English East India Company renders them very bad sovereigns, the spirit of sovereignty seems to have rendered them equally bad traders.

Adam Smith, Book V: On the Revenue of the Sovereign or Commonwealth

\section{Introduction}

State ownership of enterprise has long had its foes, who blame it for evils ranging from operational inefficiency to outright corruption. It has, nonetheless, proved to be quite resilient. The wave of privatizations that swept the world in the last decades has reduced but not eliminated government shareholdings in business corporations. State-owned enterprises (SOEs) are a fixture of the variety of capitalism embraced by today's BRICs - Brazil, Russia, India, and China - as well as other emerging economies. In the aftermath of the global financial crisis, the Leviathan as shareholder temporarily reemerged even in previously inhospitable contexts, as evidenced by the large-scale bail-outs of failing financial firms and auto companies in the United States. ${ }^{1}$

The state, however, is too often not alone in the companies it controls. Mixed corporations - here defined as firms in which the government controls the firm but shares ownership with private investors - are pervasive around the globe, and have been on the rise in a number of jurisdictions, most conspicuously China. ${ }^{2}$ The privatizations of the 1980s and 1990s were often partial in nature, with the result that the incidence of mixed enterprises effectively increased in some contexts after the state's divestitures. ${ }^{3}$ Not less important, many mixed enterprises are configured as listed firms where private investors hold minority shareholdings. As of 2010, publicly traded SOEs accounted for a startling one-fifth of the world market capitalization. ${ }^{4}$

The coexistence of government and private stockholdings in business corporations is puzzling, and has long baffled observers. The potential for conflicts of interest between private and government shareholders is evident: while private investors

\footnotetext{
${ }^{1}$ To be sure, the U.S. Treasury assumed in these cases the transient role of what President Obama called a "reluctant shareholder," and divestitures are by now well underway.

${ }^{2}$ An OECD survey estimates that, in the mid-2000, SOEs still accounted for about $50 \%$ of the market capitalization of some member countries. CORPORATE GOVERNANCE OF STATE-OWNED ENTERPRISES: A SURVEY OF OECD COUNTRIES 13 (2005). According to a recent estimate, SOEs still account for approximately $80 \%$ of the stock market value in Russia, $60 \%$ in China, and 35\% in Brazil. The Company that Ruled the Waves, The ECONOMIST, Dec. 17, 2011, at 109.

${ }^{3}$ Bernardo Bortolotti \& Mara Faccio, Government Control of Privatized Firms, 22 REV. FIN. STUD. 2907, 2907 (2009) ("[a]t the end of 2000, after the largest privatization wave in history, governments retained control of $62.4 \%$ of privatized firms").

${ }^{4}$ China Buys Up the World, The ECONOMIST, Nov. 13, 2010, at 11.
} 
presumably seek to maximize the financial returns on their stock, ${ }^{5}$ the government also has political objectives to fulfill - be they either benign (serving the public good) or malign (the product of rent-seeking). This tension has at times seemed intractable: in the mid-twentieth century, prominent French jurist George Ripert expressed a somber view of the conflicts inherent in mixed enterprises. The law, he argued, could not possibly manage to "reconcile the irreconcilable." ${ }^{\prime 6}$ In the same vein, various commentators have long forecasted the eclipse of mixed enterprise, and the ensuing convergence to either wholly public or wholly private modes of ownership and governance. ${ }^{7}$

Yet, defying predictions, this strange combination of state and private capital has not only persisted but has also appeared to thrive. China's blueprint for economic modernization included the massive floating of minority stock in government-owned firms on local and foreign stock exchanges. ${ }^{8}$ Following a combination of the global financial crisis and high oil prices, listed state-owned firms from emerging markets came to account for five out of the top ten firms in the world in market value in 2008 . Just four years before, SOEs were missing entirely from that list, which then only included private firms headquartered in the U.S. and Europe. ${ }^{9}$

Despite their economic significance, mixed enterprises have been largely neglected by the legal and economic literature, and remain little understood. In this Article, we take a different approach to this theme. In lieu of expressing surprise at the persistence of these hybrid entities or criticizing governmental involvement in what could be private firms, as does most of the extant literature, ${ }^{10}$ we inquire into the economic factors and institutional arrangements that make this form viable.

\footnotetext{
${ }^{5}$ While this is certainly the case for the modern investor-owned corporation, historically the merchant shareholders in banks, utilities and insurance companies were frequently more interested in the company's services than in maximizing their financial returns. See Henry Hansmann \& Mariana Pargendler, The Evolution of Shareholder Voting Rights: Separation of Ownership and Consumption (unpublished working paper, 2012) (on file with authors).

${ }^{6}$ GEORGES RIPERT, AsPeCTS JURIDIQUE DU CAPITALISME MODERne [Legal Aspects of Modern Capitalism] 318 (1946) (free translation) (“[1]a loi peut tout, sauf arriver a concilier ce qui est inconciliable”).

${ }^{7}$ See, e.g., Bilac Pinto, O Declínio das Sociedades de Economia Mista e o Advento das Modernas Empresas Públicas [The Decline of Mixed Enterprise and the Advent of the Modern Public Enterprise], in ESTUDOS SOBRE A CONSTITUIÇÃO BRASILEIRA (1954) (forecasting that, in light of the significant conflicts between state and private, mixed corporations would soon be eclipsed by wholly-owned government corporations). For a recent critique of hybrid firms, see Schumpeter: The rise of the hybrid company (The problem with state-backed firms), THE ECONOMIST, Dec. 5, 2009 (arguing that "[t] he clearer the line between the state and the private sector, the better it is for those on both sides").

${ }^{8}$ See, e.g., Cyril Lin, Corporatisation and Corporate Governance in China's Economic Transition, 34 ECONOMICS OF PLANNING 5 (2001) (describing the dominance of state-owned firms in China's securities markets).

${ }^{9}$ Kate Burgess, OECD Scrutinises State Owned Groups, F.T., June 20, 2008 (noting that "[o]nly four years ago, the world's 10 largest listed companies in terms of market value were private commercial entities domiciled in the US and Europe. Today, five of the top 10 publicly traded corporations are government controlled").

${ }^{10}$ For excellent surveys, see William L. Megginson \& Jeffry Netter, From State to Market: A Survey of Empirical Studies on Privatizations, 39 J. Econ. LiT. 321 (2001); Mary M. Shirley \& Patrick Walsh, Public Versus Private Ownership: The Current State of the Debate (World Bank Policy Research Working Paper No. 2420, 2001), available at http://papers.ssrn.com/sol3/papers.cfm?abstract_id=261854. See also notes 6 and 7 supra and accompanying text. As an exception to this trend, see Andrea Colli,
} 
What explains this mode of organization? Why would the government take part in for-profit enterprise? Even more troubling, why would private investors agree to partner up with the government, when it is the majority shareholder? What role does the law can play in allowing the state to credibly commit to tie its hands as a controlling shareholder?

In order to shed light on these questions, we will first introduce an analytical framework to address the costs and benefits of this organizational form. One could be tempted to view mixed enterprises as the ultimate device for achieving the best of both worlds. They could, in theory, attain the efficiency of private enterprise and mitigate market failures in the public interest all the same time. Yet once we realistically account for the prospect of government failures, the story is not quite so simple. If operational distortions due to politically-motivated interventions are not kept in check, the benefits of partial private ownership might come to vanish. Conversely, if the firm were to be managed as a wholly private concern, the practical utility of having the government as a controlling shareholder would come into question.

We argue that the effectiveness of mixed enterprise depends on a hybrid governance structure that combines elements of private ownership with public checksand-balances against uncertain governmental interference. This is a delicate equilibrium to obtain - and one not without challenges. We explore the promise and perils of this approach by looking at the recent experience of a sample of national oil companies (NOCs): Brazil’s Petrobras, Norway’s Statoil, and Mexico’s Pemex.

A number of factors make oil companies a particularly interesting object of study for our purposes. First, NOCs are arguably the most important SOEs in the world: they control around 90 percent of the world's oil reserves and 75 percent of oil and gas production. ${ }^{11}$ Second, the oil industry offers the full spectrum of ownership forms and market structures. Among the largest oil companies, there are private, public, and mixed enterprises - which in turn are subject to different constraints in terms of regulation and competition. Third, because NOCs mediate the stream of rents governments receive from the exploitation of oil and gas reserves, it is in these firms that the government's temptation to intervene in SOE management to pursue social goals could be greatest. That is, it is NOCs that governments usually want to be less transparent about how they manage their revenues. ${ }^{12}$

The Article proceeds as follows. Part I presents an analytical framework to examine mixed enterprises as an organizational form from an economic perspective. It

Coping with the Leviathan: Minority Shareholders in State-owned Enterprises - Evidence from Italy, 2012 BUSINESS HISTORY 1 (investigating the factors that attracted private investors to SOEs in the Italian context).

${ }^{11}$ Moreover, analysts estimate that 60 percent of the world's undiscovered reserves are in countries in which NOCs are dominant players. Silvana TORdo, BrANDON Tracy \& NOORA ARFAA, NATIONAL OIL COMPANIES AND VALUE CREATION (2011).

${ }^{12}$ Michael Ross, The Oil Curse: How Petroleum Wealth Shapes the Development of Nations (2012). 
does so by comparing the costs and benefits of joint public-private ownership with its polar alternatives - private firms, on the one hand, and wholly-owned state enterprise, on the other - from the perspective of a social planner. Part II then tackles the puzzle of private shareholdings in SOEs, by describing the legal and extralegal mechanisms that encourage private actors to co-invest with the state. In Part III, we examine how these arrangements operate in practice by taking a closer look at the corporate governance and performance of three giant national oil companies: Norway's Statoil, Brazil's Petrobras, and Mexico’s Pemex. Part IV concludes.

\section{The economics of mixed enterprise}

Traditionally, the economic justification for state ownership of enterprise lies in the presence of a market failure. ${ }^{13}$ Whenever one or more of the requisites for perfect competition are lacking, free markets no longer guarantee an efficient allocation of resources - with the result that, at least in theory, there could be a case for government ownership. This line of reasoning has over time been used to explain and justify the governmental provision of quintessential public services, such as roads and bridges (which are natural monopolies), national security (which is a public good) and education (an area in which positive externalities are particularly significant), to name only a few prominent examples. In developing countries, severe capital market failures also account for state ownership of capital-intensive undertakings regardless of industry characteristics. $^{14}$

Conversely, critics of state intervention have drawn attention to the fact that the mere presence of a market failure is not, in itself, sufficient to warrant government ownership of enterprises. If markets fail, so does government action, ${ }^{15}$ for multiple reasons, ranging from the difficulty in aggregating preferences through the voting mechanism, ${ }^{16}$ to collective action problems and the corresponding distorted incentives that accompany state policy and action, leading it to favor special interest groups over general welfare. ${ }^{17}$ The specter of government failure hence suggests caution at both about the need for state intervention and the precise contours such intervention should assume.

Most of the economic literature favoring privatizations of SOEs focuses on one particular alternative to state ownership: the combination of private ownership and

\footnotetext{
${ }^{13}$ See, e.g., Andrei Shleifer, State Versus Private Ownership, 34 J. ECON. PERSP. 133, 144 (1998) ("Half a century ago, economists were quick to favor government ownership of firms as soon as any market inequities or imperfections, such as monopoly power or externalities, were even suspected").

${ }^{14}$ For a discussion, see Ha-Joon Chang, State-owned Enterprise Reform, in NATIONAL DEVELOPMENT STRATEGIES - POLICY NOTES 12 (UNDESA - United Nations Department of Social and Economic Affairs ed., 2008).

${ }^{15}$ Ronald Coase, The Problem of Social Cost, 3 J. L \& ECON. 1, 18 (1960).

${ }^{16}$ KeNNETH J. ARROW, SOCIAL CHOICE AND INDIVIDUAL VALUES (1963).

${ }^{17}$ See, e.g., Mancur Olson, The Logic of Collective Action (1965); Mancur Olson, The Rise and DECLINE OF NATIONS (1982).
} 
government regulation. This approach, the theory goes, had significant advantages: while regulation mitigated market failures, the incentives inherent to private ownership helped ensure efficiency in operational performance and innovation. ${ }^{18}$ As its very proponents acknowledged, however, this approach was not free from difficulties: whenever contracting costs were particularly severe - thus reducing the effectiveness of regulation - public ownership could offer a superior arrangement. ${ }^{19}$

Mixed enterprise provides another important, but mostly undertheorized, organizational alternative to mitigate the drawbacks of both market and government failures. Instead of inexorably resorting to private ownership and regulation, various governments around the world viewed the listing of state-owned enterprises as a midway solution to most of the problems associated with state ownership. As we explore in Part III, in the oil industry, too, there has been a visible trend towards the corporatization and listing of large national oil companies. ${ }^{20}$

We focus on three primary factors that make this hybrid organizational form potentially appealing to a social planner. The first one is its promise for regulatory effectiveness compared to a regime of arm's-length regulation. In economic parlance, mixed enterprise differs from the standard combination of private ownership and government regulation in that it entails the vertical integration of the state's regulatory function. ${ }^{21}$ It economizes on the transaction costs associated with writing and enforcing regulations, since the government enjoys greater discretion to adapt its policies in view of changing circumstances through its voice within the firm's hierarchy. This organizational form might be particularly fitting in environments where contracting institutions are weak, thus hampering the enforcement of regulations, or where noncontractible national security or sovereignty considerations come into play. ${ }^{22}$

The advantage of regulatory effectiveness relates to the social view of SOEs. ${ }^{23}$ In this view, SOEs differ from private enterprise primarily due to the pursuit of a "double bottom-line." That is, in addition to producing profits, state control over the

\footnotetext{
${ }^{18}$ Id. at 135.

${ }^{19}$ The apparently dire experience with prison privatizations in the United States provides a case in point. Oliver Hart, Andrei Shleifer \& Robert Vishny, The Proper Scope of Government: Theory and an Application to Prisons, 112 QUART. J. ECON. 1127 (1997). However, other authors have proposed that incomplete contracting in the context of public services can be possibly solved with a combination of private operation and public (on site) monitoring. Sandro Cabral, Sergio G. Lazzarini \& Paulo Furquim de Azevedo, Private Operation with Public Supervision: Evidence of Hybrid Modes of Governance in Prisons, 145 PuBlic CHOICE 281 (2010).

${ }^{20}$ See note 45 infra and accompanying text.

${ }^{21}$ See, e.g., JeAn-Jacques Laffont \& Jean Tirole, A Theory of Incentives in Procurement and REGULATION 638 (1993) (describing the existence of internal, in addition to external, government control as the defining feature of government enterprise). Such vertical integration, however, need not be complete. As Statoil's experience demonstrates, state-owned firms can be subject to strong regulatory authorities.

${ }^{22}$ Shleifer, supra note 13; Oliver E. Williamson, Public and Private Bureaucracies: A Transaction Cost Economics Perspective, 15 J. L. ECON. \& ORG. 306 (1999).

${ }^{23}$ Eduardo Levy Levy-Yeyati, Alejandro Micco \& Ugo G. Panizza, Should the Government Be in the Banking Business? The Role of State-Owned and Development Banks (November 2004). IDB Working Paper No. 428, available at http://ssrn.com/abstract=1818717.
} 
firm can also be used to promote a public purpose, be it low price to consumers, environmental sustainability, or a given macroeconomic objective, from inflation control to reduced unemployment. In a mixed enterprise, however, the pursuit of a double bottom-line is at odds with the interests of private investors, which then might exercise pressure on the firm to ditch its public objectives. But the alternative of whole ownership by the state brings about costs of its own: as the government replaces private control of the enterprise, the efficiency benefits usually associated with private ownership diminish accordingly.

The second positive feature of mixed enterprise is precisely the promise that, by welcoming private shareholders in government-controlled firms, improvements in operational efficiency will follow. The academic literature has indeed found evidence that, although mixed, generally supports the view that the listing of SOEs on domestic and international stock exchanges contribute to more efficient management. ${ }^{24}$ Megginson summarizes a series of studies that provide overwhelming support for improvements in performance when SOEs' stocks are publicly traded. ${ }^{25}$ Likewise, Gupta finds that government-controlled companies which sold minority positions to private investors perform better than wholly-owned SOEs in India. ${ }^{26}$

Different channels can explain the observed positive effects of the floating of SOEs' stock on firm performance, both from an agency and political views. According to the agency view of SOE inefficiency, the absence of private owners imbued with profit motive decreases the incentives for competent firm management. According to the political view, the administration of SOEs may too often be captured by the rentseeking ambition of powerful special interest groups. ${ }^{27}$

Listing of mixed enterprises has been indicated as a possible solution to those potential conflicts. ${ }^{28}$ In Table 1 , we summarize how the listing of SOEs affects performance and incentives compared to whole ownership by the state. To begin with, listed mixed enterprises are subject to greater monitoring by private investors compared to wholly-owned government firms. To be sure, the latter could, in theory, also count on

\footnotetext{
${ }^{24}$ Both theoretical and empirical works generally support the view that the floating of minority stock is beneficial compared to whole ownership by the government. See Catherine C. Eckel \& Aidan R. Vining, Elements of a Theory of Mixed Enterprise, 32 Scot. J. PoL. ECON. 82 (1985), for a theoretical model suggesting that mixed enterprises may perform better than SOEs, but worse than private firms; Aidan R. Vining \& Anthony E. Boardman, Ownership Versus Competition: Efficiency in Public Enterprise, 73 PuB. CHOICE 205, 222 (1992) (finding that mixed enterprises are more profitable than wholly-owned SOEs, but less profitable than private firms); Sumit K. Majumdar, Assessing Comparative Efficiency of the State-Owned Mixed and Private Sectors in Indian Industry, 96 PUB. CHOICE 1, 13 (1998) (concluding that mixed enterprises perform better than wholly-owned SOEs, but worse than private firms).

${ }^{25}$ William L. Megginson, The Financial Economics of Privatization 106-7 (2005).

${ }^{26}$ Nandini Gupta, Partial Privatization and Firm Performance, 60 J. FIN. 987 (2005).

${ }^{27}$ For a detailed discussion of the agency and political views of SOE inefficiency, see Rafael La Porta \& Florencio López-de-Silanes, The Benefits of Privatization: Evidence from Mexico, 114 Quart. J. Econ. 1193 (1999); Aldo Musacchio \& Sergio G. Lazzarini, Leviathan in Business: Varieties of State Capitalism and Their Implications for Economic Performance, Harvard Business School Working Paper No. 12-1082012, available at http://papers.ssrn.com/sol3/papers.cfm?abstract_id=2070942.

${ }^{28}$ Gupta, supra note 26.
} 
private creditors as potential monitors - in so far as they resort to bank credit and/or bond issuances, as they habitually do in practice. Nevertheless, the borrowing capacity of government firms is often attributable to an implicit bailout guarantee by the government. This implicit bailout contract, in turn, provides disincentives for creditors to monitor the firm's day-to-day management. By contrast, equity investors in listed SOEs face, in principle, stronger incentives to avail themselves of both voice (provided they enjoy voting rights or board representation) and exit (by selling stock, thus depressing share prices) in disciplining management.

Moreover, the very availability of stock prices serves an important function: it provides the government and the market with timely information about enterprise value, which can, in turn, be used to monitor managerial performance or even to design incentive-based compensation packages. Finally, as further discussed below, mixed enterprises are generally subject to the same legal regime applicable to private firms, which can serve as a further constraint to mismanagement, hence boosting operational performance. For instance, listed SOEs invariably need to produce financial statements audited by a recognized private firm, a feature which is often unavailable when the government is the sole owner.

Third, another rationale for mixed enterprise is that it allows new investments in riskier projects with a longer-term perspective. Mixed ownership permits the government to share risk with private investors over uncertain ventures. The stock offering by Brazil's Petrobras in 2010 to fund the requisite deep-water technology to explore the newly-discovered pre-salt oil fields provides a case in point. ${ }^{29}$ To be sure, market investors tend to emphasize short-term profitability and may be less "patient" to accept riskier, longer-term investments. This fact notwithstanding, market pressure may help avoid short-term pressure in the other direction: governments may want to use SOEs to reap dividends associated with the political cycle (e.g. lowering prices to final consumers in election years).

Finally, despite the apparent potential for greater private meddling in public affairs, listed SOEs might be appealing even for the most committed defenders of government intervention. Partial state ownership does not chip away but rather reinforces the state's grip over the economy through "leverage" - a motive which was arguably at the heart of China's decision to list minority stakes in its SOEs. ${ }^{30}$ That is, the presence of private shareholders allows the state to exercise control over a larger number of firms without making a commensurate financial investment. In fact, a fair number of mixed enterprises have historically resorted to minority-control structures via corporate pyramids or the issuance of non-voting stock to the public - through which the state held uncontested control while holding less than a majority of the total

\footnotetext{
${ }^{29}$ See Part III infra.

${ }^{30}$ Donald Clarke, Corporatisation, Not Privatisation, 7 CHINA L. \& ECON. QuART. 27, 28 (2003) (explaining that "[a]n explicit goal of enterprise reform [in China] is the magnification of state control through leverage," a concept that is "enshrined in a key Communist Party decision document from 1999”). Clarke argues that "the apparent dilution of state ownership through the sale of shares in listed companies, which leads some observers to assume the inevitability of eventual privatization, is in fact a mechanism for expanding the state's economic empire.”
} 
capital. $^{31}$ In this respect, it is curious that the incidence of mixed enterprises has been comparatively greater in more coordinated civil-law countries than in more liberal common-law countries, as the latter have more frequently opted for either wholly public or private modes of governance. ${ }^{32}$

Table 1. The Governance of Wholly-Owned vs. Listed State-Owned Enterprises

\begin{tabular}{|c|c|c|}
\hline $\begin{array}{l}\text { Theory of SOE } \\
\text { inefficiency }\end{array}$ & $\begin{array}{l}\text { Features of enterprises with sole } \\
\text { government control }\end{array}$ & $\begin{array}{l}\text { How does listing change that } \\
\text { feature? (Mixed enterprises) }\end{array}$ \\
\hline \multirow[t]{3}{*}{ Social view } & $\begin{array}{l}\text { Solves difficulty of regulating } \\
\text { natural monopolies. Government } \\
\text { self-regulates }\end{array}$ & $\begin{array}{l}\text { Government can still self-regulate, } \\
\text { but can be more efficient at } \\
\text { producing goods (reducing marginal } \\
\text { costs) }\end{array}$ \\
\hline & $\begin{array}{l}\text { Double bottom line (e.g. profit } \\
\text { maximization jointly with other } \\
\text { social objectives such as low } \\
\text { inflation or higher employment) }\end{array}$ & $\begin{array}{l}\text { Maximization of shareholder value } \\
\text { subject to political interference if } \\
\text { the company is not insulated. } \\
\text { Likely conflict if minority } \\
\text { shareholders pursuing profitability } \\
\text { clash with governments following } \\
\text { social or political goals. }\end{array}$ \\
\hline & $\begin{array}{l}\text { Long-term horizon, government as } \\
\text { patient investor tolerating losses }\end{array}$ & $\begin{array}{l}\text { Likely shorter-term horizon, } \\
\text { markets are generally impatient with } \\
\text { respect to losses; yet market } \\
\text { pressure can avoid short-term } \\
\text { pressure due to political cycles }\end{array}$ \\
\hline \multirow[t]{2}{*}{ Political view } & $\begin{array}{l}\text { Appointment of CEOs using criteria } \\
\text { other than merit (e.g., political } \\
\text { connections) }\end{array}$ & $\begin{array}{l}\text { Professional management selected } \\
\text { by the board of directors. } \\
\text { Government has strong influence as } \\
\text { majority shareholder. }\end{array}$ \\
\hline & $\begin{array}{l}\text { Poor monitoring: no board of } \\
\text { directors (ministry regulates) or } \\
\text { politically appointed board (low } \\
\text { level of checks and balances) }\end{array}$ & $\begin{array}{l}\text { Board of directors with some } \\
\text { independent members and some } \\
\text { political appointees; depending on } \\
\text { numbers, it can act as a balance to } \\
\text { the government and the CEO. Yet, } \\
\text { government can co-opt board } \\
\text { members. }\end{array}$ \\
\hline
\end{tabular}

\footnotetext{
${ }^{31}$ The ownership structure of Brazil's formerly state-owned telecom company Telebras provides a case in point. Through the use of non-voting shares and a pyramidal structure, the state was able to exercise uncontested control while holding less than one-fifth of the firm's total equity capital. Mariana Pargendler, State Ownership and Corporate Governance, 80 FordHAm L. REV. 2917, 2939 (2012). For various examples of the use of corporate pyramids by the Italian state, see Colli, supra note 10, at 4-9.

32 Id. at 2951-60; John Thurston, GOvernment Proprietary Corporations in the EnglishSPEAKING COUNTRIES 5 (1937).
} 
Government uses SOEs to smooth business cycles (e.g., hiring more or firing fewer workers than necessary)
Effect is reduced if the firm is isolated from political intervention.

\begin{tabular}{lll}
\hline Soft budget constraint (bailouts) & $\begin{array}{l}\text { No clear risk of bankruptcy } \\
\text { (governments will likely bail them } \\
\text { out) }\end{array}$ \\
\hline Agency view & $\begin{array}{l}\text { Management has low-powered } \\
\text { incentives }\end{array}$ & $\begin{array}{l}\text { Pay-for-performance contracts, } \\
\text { bonuses, and stock options more } \\
\text { likely }\end{array}$ \\
\hline $\begin{array}{l}\text { Hard to measure performance } \\
\text { (financial measures are not enough, } \\
\text { not easy to measure social and } \\
\text { political goals) }\end{array}$ & $\begin{array}{l}\text { Stock prices and financial ratios as } \\
\text { satisfaction and feedback to } \\
\text { measure quality of goods and/or } \\
\text { services. }\end{array}$ \\
\hline $\begin{array}{l}\text { No clear punishment for managers } \\
\text { who underperform }\end{array}$ & $\begin{array}{l}\text { Boards may fire managers who } \\
\text { underperform }\end{array}$ \\
\hline $\begin{array}{l}\text { Ministries and agencies with weak } \\
\text { incentives to monitor }\end{array}$ & $\begin{array}{l}\text { Boards may fire managers who } \\
\text { underperform }\end{array}$ \\
\hline $\begin{array}{l}\text { No transparency: incomplete } \\
\text { financial information }\end{array}$ & $\begin{array}{l}\text { Improved transparency; accounting } \\
\text { standards following GAAP or IFRS }\end{array}$ \\
\hline $\begin{array}{l}\text { Boards packed with politicians or } \\
\text { bureaucrats (exacerbates political } \\
\text { intervention and double-bottom } \\
\text { line) }\end{array}$ & $\begin{array}{l}\text { Boards as principals of CEO } \\
\text { (monitoring/punishing) }\end{array}$ \\
\hline
\end{tabular}

\section{Understanding private investment in SOEs}

The previous section identified the factors and circumstances that render mixed enterprises an attractive instrument from the perspective of a social planner. But the fact that governments may see benefits in sharing ownership with private investors does not entail that the latter will be willing to come on board. One crucial part of the story hence remains unexplained: why would private investors opt to join forces in a for-profit corporation with the state - an extremely powerful partner which most certainly has interests and objectives which are divergent from their own?

\section{A. Involuntary private investment}

Before we attend to this puzzle, it is worth noting that not all mixed enterprises originate from a voluntary investment by private shareholders. On the contrary, historical examples abound of situations in which private investors had little or no choice with respect to the presence of the state as a majority shareholder in the firm. The most extreme instances of this phenomenon concern partial nationalizations in the face of an actual or perceived crisis. 
State takeovers of enemy property during wartime illustrate this point. While cases exist where all of a company's capital stock was the object of expropriation, governments often acquired partial (though usually controlling) stakes in these foreignowned firms. In a study conducted by Kole and Mulherin on 17 nationalizations of enemy property by the U.S. government during World War II, the authors found that only six of these seizures entailed the acquisition of the totality of the firm's shares. The mean and median stakes acquired by the government were 75 and 77 percent, respectively - which meant that in most companies the state opted to join forces with private shareholders instead of having the firm all for itself. ${ }^{33}$

But it is economic rather than military considerations that have most often forged the state's incursion into private firms. In fact, the line between voluntary and involuntary partnering up with the state is sometimes a thin one. In the nineteenth century, prior to the advent of general incorporation, revenue-hungry state governments in the United States habitually conditioned the grant of a corporate charter on a gift of presumably lucrative stocks (as well as the extension of loans) to the state. ${ }^{34}$ The same type of exchange of stock for the privilege of incorporation also occasionally occurred in nineteenth-century Brazil. ${ }^{35}$ Although corporate promoters in such cases technically consented to the state's shareholdings, their only alternative would likely have been to forego the venture altogether.

More commonly, however, the acquisition of an equity stake by the government - even if paid for - is a unilateral move by Leviathan. In response to the 2008 financial crisis, the bail-outs of then failing firms such as Citigroup, ${ }^{36} \mathrm{AIG},{ }^{37}$ and General Motors ${ }^{38}$ by the U.S. federal government have all taken the form of capital infusions that resulted in partial rather than whole equity ownership by the state. Argentina's recent nationalization of oil company YPF in 2012 was also partial in nature: President Cristina Fernández's administration expropriated the controlling block held by Spanish

\footnotetext{
${ }^{33}$ Stacey R. Kole \& J. Harold Mulherin, The Government as a Shareholder: A Case from the United States, 40 J.L. \& ECON. 1, 6-7 (1997).

${ }^{34}$ Anna Jacobson Schwartz, The Beginning of Competitive Banking in Philadelphia, 1782-1809, $55 \mathrm{~J}$. POL. ECON. 417, 418-9 (1947) (describe the state's subscription of stock in the Bank of Pennsylvania in exchange for the approval of its charter); John Joseph Wallis, Constitutions, Corporations, and Corruption: American States and Constitutional Change, 1842 to 1852, 65 J. ECON. HIST. 226-230 (2005)(explains different ways in which state governments in the United States financed infrastructure and bank companies). LAWRENCE M. Friedman, A History OF AMERICAN LAW 133 (3d ed. 2005) (recounts how the grant of monopoly rights to the Camden and Amboy railroad resulted from a major gift of stock to the State of New Jersey).

${ }^{35}$ See, e.g., Companhia de Mineração de Cuyabá, incorporated by Carta Régia [Royal Charter] (Jan. 16, 1817).

${ }^{36}$ Jonathan Stempel, U.S. Becomes Citigroup's Biggest Shareholder, ReUTERS (Jul. 30, 2009), http://www.reuters.com/article/2009/07/30/us-citigroup-stake-idUSTRE56S3J120090730 (reports the acquisition of a $34 \%$ stake by the federal government).

${ }^{37}$ Gretchen Morgenson, Greenberg Sues U.S. Over A.I.G. Takeover, N.Y. TiMES, Nov. 21, 2011, at B2 (refers that the U.S. acquisition of $80 \%$ of the firm's equity took place "over the objection of shareholders").

${ }^{38}$ Jim Kuhnhenn \& Ken Thomas, Government Motors: US Will Own 60\% of GM, HufFINGTON PosT, June 1, 2009, http://www.huffingtonpost.com/2009/05/31/government-motors-us-will_n_209578.html.
} 
private company Repsol while maintaining intact the minority public float on the Buenos Aires stock exchange held mostly by foreign institutional investors and by Argentine private shareholders. Both the efficiency advantages discussed in Part I and the lower cost of taking control compared to whole ownership help explain why governments might prefer to promote partial rather than full nationalizations.

If the involuntary nature of private participation partially solves the riddle, it brings about greater apprehension in terms of property rights' protection and public policy. There is little question that the emergence of the government as the controlling shareholder tends to alter the firm's objectives and management profile, as the state may be tempted to pursue political objectives that are inconsistent with profit maximization. This concern for the interests of private shareholders who did not consent to the government's takeover implicitly underlies the critical commentary on the financial crisis bail-out and the role of the U.S. government as a shareholder. ${ }^{39}$ It is precisely to avoid these risks that Brazil's Corporations Law, for instance, grants appraisal rights to minority shareholders in the event the government takes control of a private company. ${ }^{40}$

\section{B. Voluntary private investment}

It is clear that not all mixed enterprises result from deliberate private investment in SOEs. While this makes the initial puzzle smaller than it appeared at first, the persistent presence (and apparent expansion in recent years) of voluntary investment in listed SOEs is both significant and little understood. In many countries around the world, equity markets are underdeveloped - it being difficult enough to convince investors to buy minority positions in any publicly-traded firm. ${ }^{41}$ Investing together with the government itself - a powerful actor with multiple and varying objectives should, in principle, amount to an even more daunting proposition. Yet the evidence shows that private shareholders are not as averse to investing in SOEs as one might have expected.

Voluntary private investment in SOEs takes two primary forms depending on the firm's initial ownership structure: it can be present since the company's inception or result from partial privatizations of wholly-owned SOEs. Although less common in recent times, the first model was historically dominant. In the nineteenth-century United States, state and local governments habitually acquired stocks in public improvement companies, either to obtain a new source of revenue, as previously discussed, ${ }^{42}$ or to

\footnotetext{
${ }^{39}$ See, e.g., Marcel Kahan \& Edward B. Rock, When the Government is the Controlling Shareholder, 89 TEX. L. REV. 1293 (2011); J.W. Verret, Treasury Inc.: How the Bailout Reshapes Corporate Theory and Practice, 27 Yale J. Reg. 283 (2010).

${ }^{40}$ Art. 36, sole paragraph, Lei No. 6.404, de 15 de Dezembro de 1976, DiÁRIO OfiCial DA União [D.O.U.] de 17.12.1976 (Braz.).

${ }^{41}$ Bernard S. Black, The Legal and Institutional Preconditions for Strong Securities Markets, 48 UCLA L. REV. 781, 782 (2001) ("That securities markets exist at all is magical, in a way. Investors pay enormous amounts of money to strangers for completely intangible rights, whose value depends entirely on the quality of the information that the investors receive and on the sellers' honesty. Internationally, this magic is rare").

${ }^{42}$ See note 34 supra and accompanying text.
} 
help finance a critical element of the infrastructure in the region. ${ }^{43}$ Similarly, a number of prominent Brazilian SOEs - such as steel giant Companhia Siderúrgica Nacional (CSN) and Petrobras - were at least formally created as mixed enterprises from the outset in the 1950s, but it took a while and substantial promotional efforts for private investors to flock in. ${ }^{44}$

Yet an even more substantial number of listed SOEs have received private investment as a result of the government's partial divestiture of what were previously wholly-owned subsidiaries. Norway's listing of Statoil in 2001 is but one of numerous such examples. Precisely half of the world's 30 largest national oil companies are listed SOEs. ${ }^{45}$ With the exception of Petrobras, which has been listed on Brazilian stock exchanges for decades (even though none of its voting stock was traded until 2001), all of these listed national oil companies were previously wholly-owned SOEs that have floated minority shares in local and foreign stock exchanges in the 1990s and early 2000s. ${ }^{46}$

The listing of SOEs, in turn, can be an end state or an initial step in the process towards full transition from state to private ownership. Norway, for instance, has demonstrated a commitment to maintaining state control and production in the country. ${ }^{47}$ The option for the first possibility is typically driven by the economic considerations discussed in Part I. The choice for partial privatizations as an intermediary and temporary stage can be due to different economic considerations. First, even if governments have decided to divest their holdings in full, floating $100 \%$ of the firm's stock at once could reduce share prices, so revenue maximization may be best served by successive offerings in smaller installments. Another explanation for paced divestments has to do with the risk of policy reversal. Enrico Perotti has posited that gradual sales of shares in privatized firms can also perform a commitment function in order to allow the government to progressively establish policy credibility by bearing residual risk. ${ }^{48}$

\section{Legal factors}

Taming the state and taming controlling shareholders are both major institutional challenges in their own right. It should therefore come as no surprise that taming Leviathan as a majority shareholder is a particularly intricate task for which there is no

\footnotetext{
${ }^{43}$ See, e.g., Louis Hartz, Economic Policy and Democratic Thought: Pennsylvania, 1776-1860 94 (1948).

${ }^{44}$ On Petrobras, see Part III infra. As Levy reports, the Brazilian government faced substantial difficulty in attracting private investment to CSN in its early days. Private shareholders only gradually came in, following an aggressive publicity campaign and, more importantly, a government interest guarantee of 6\% while dividends fell below that amount. MARIA BARBARA LEVY, A INDÚSTRIA DO RIO DE JANEIRO ATRAVÉS DE SUAS SOCIEDADES ANÔNIMAS 269-270 (1994).

${ }^{45}$ Oil and Governance: State-Owned EnTERPRises AND the World Energy Supply (David G. Victor, David R. Hults \& Mark C. Thurber eds., 2012).

${ }^{46}$ Authors' calculations based on information available on the companies' websites.

${ }^{47}$ See Part III infra.

${ }^{48}$ Enrico Perotti, Credible Privatization, 85 Am. ECON. Rev. 847 (1995).
} 
clear-cut solution. These hybrid entities are thus subject to hybrid legal regimes and modes of governance. We show that this intriguing organizational form is the result of multiple legal and extralegal factors - neither of which alone nor in combination provide a bulletproof solution to the perils of state control of business ventures. Taken together, however, they provide sufficient checks and balances, making mixed enterprises far more workable and durable than most would have expected.

As suggested by the extensive and controversial literature on "Law and Finance," legal protection for minority investors is an important determinant of the demand for stocks in publicly-traded companies and, consequently, for the observed level of capital market development. ${ }^{49}$ We argue here that legal protections and constraints are an integral ingredient for the success of the mixed enterprise form, and a factor encouraging private investors to join in. We approach this theme by examining three categories of legal factors that provide assurance to private shareholders in SOEs: (i) private law protections, (ii) public law constraints, and (iii) legal privileges.

\section{Private law protections}

\section{a. $\quad$ Corporate and securities laws}

Mixed enterprises are typically organized as business corporations. Subject to a few punctual exceptions - specified in the laws that create them or in a discrete statutory section of the corporations statute - listed SOEs are generally subject to the same corporate and securities laws applicable to private firms. To quote a French observer of then contemporary nationalizations of the 1940s, the state "had expropriated capitalists not only of their enterprises, but also of their experience and their recipes." 50

The application of a single legal regime for state-controlled and private firms is customary and considered a "best practice" for SOEs by the influential OECD Guidelines on Corporate Governance of State-Owned Enterprises. ${ }^{51}$ But as one of us has previously argued, this policy choice is not without costs. Because the interests of the state as a controlling shareholder often play a prominent role in corporate law reforms, the ensuing unitary corporate law regime (applicable to both state and private firms) may turn out to afford insufficient protection of minority shareholders. ${ }^{52}$

From the perspective of outside investors in SOEs, however, the application of a private law regime provides greater assurance both as to the content and the stability of

\footnotetext{
${ }^{49}$ For a review of this literature, see Rafael La Porta, Florencio Lopez-de-Silanes \& Andrei Shleifer, The Economic Consequences of Legal Origins, 46 J. ECON. LiT. 285 (2008).

${ }^{50}$ R. Houin, La Gestion des Entreprises Publiques et les Methods de Droit Commercial, in ARCHIVES DE Philosophie du Droit: LA Distinction du Droit PRIVE ET DU DRoIT PubliC DE L'ENTERPRISE PubliQue 79 (1952) (quoting G. Vedel, « La technique des nationalisations », Droit social, 1946, p. 96: L’Etat a « exproprié les capitalistes non seulement de leurs entreprises, mais de leur expérience et de leurs recettes »).

${ }^{51}$ OECD, OECD Guidelines On CORPORATE GOVERnANCE OF STATE-OWNED ENTERPRISES (2005).

52 Pargendler, State Ownership, supra note 31; Mariana Pargendler, The Unintended Consequences of State Ownership: The Brazilian Experience, 13 THEORETICAL INQ. L. 503 (2012).
} 
the underlying rules of the game. At the very least, it makes it costlier for the state to overhaul the legal regime in view of its short-term interests. In other words, a unitary legal regime provides a useful, albeit imperfect, way for the government to credibly commit to protect private investors.

Although the degree of legal investor protection and its enforcement varies widely around the world, ${ }^{53}$ certain features are recurrent. Securities laws typically mandate the timely disclosure of material information on the company as well as the periodical publication of audited financial statements. This, in turn, permits market participants to monitor the company's performance, so that stock prices will reflect a combination of the firm's fundamentals and the prospect of expropriation. Most corporate laws also impose (with varying degrees of effectiveness) limitations on tunneling and self-dealing transactions by managers and controlling shareholders. ${ }^{54}$

Nonetheless, the submission of SOEs to general private and securities laws while helpful in providing assurance to its investors - does not guarantee that SOEs will behave like a private firm. First, there is still the possibility of differential enforcement of facially uniform regulations, with SOEs effectively being subject to more lenient standards. There is evidence suggesting that this may be often the case. Even though SOEs dominate China's capital markets, they receive fewer sanctions from the securities agency than do private firms. ${ }^{55}$ An event study of Chinese corporate law reforms in 2000 showed that only private firms, but not SOEs, experienced abnormal positive returns following the enactment of new regulations - hence implying that markets do not expect enforcement of stricter standards against government-controlled companies. ${ }^{56}$ In Brazil, too, the securities commission was historically reluctant to punish SOEs for securities laws violations. ${ }^{57}$

The internal governance structure of listed SOEs - be it legally mandated or voluntarily adopted - also provides for another set of checks and balances. The state usually holds a majority of the voting stock in mixed enterprises, which puts it in a position of dominance in the general assembly. A number of listed SOEs, however, grant voting rights to outside shareholders, which allow them to participate in the shareholders' meeting and, occasionally, even have a deciding voice in matters where the government as controlling shareholder is conflicted, as is the case under Brazilian law.

\footnotetext{
53 John C. Coffee, Jr., Law and the Market: The Impact of Enforcement, 156 U. PA. L. REV. 229 (2007).

${ }^{54}$ Simeon Djankov et al., The Law and Economics of Self-Dealing, 88 J. Fin. Econ. 430 (2008).

${ }^{55}$ William T. Allen \& Han Shen, Assessing China's Top-Down Securities Markets, in CAPITALIZING CHINA (Joseph Fan \& Randall Morck eds., 2012).

${ }^{56}$ Henk Berkman, Rebel A. Cole \& Lawrence J. Fu, Political Connections and Minority-Shareholder Protection: Evidence from Securities-Market Regulation in China, 45 J. Fin. \& QuANTITATIVE ANALYSIS 1391 (2011). See also William T. Allen \& Han Shen, Assessing China's Top-Down Securities Markets, in CAPITALIZING CHINA (Joseph Fan \& Randall Morck eds., 2012).

${ }^{57}$ Pargendler, Unintended Consequences, supra note 52; Arnoldo Wald, Trinta Anos da Lei do Mercado de Valores Mobiliários no Brasil [Thirty Years of Securities Laws in Brazil], 34 Revista DE Direito BANCÁRIO E DO MERCADO DE CAPITAIS 5, 5 (2006) (noting that the securities' commission lack of independence in its earlier years hampered enforcement actions against SOEs).
} 
Listed SOEs also tend to have hybrid boards in one form or another. Their hybrid character might derive from a combination (and tension) between technical experts and political appointees, the presence of independent directors, or minority shareholder representatives to the board, or a mixture of these features. Employee board representation (also known as "codetermination”) is also particularly common on SOE boards. ${ }^{58}$ Although shareholders and employees usually have clashing interests, labor representatives in this context might still provide a useful layer of monitoring against outright abuse, waste or corruption by the government. ${ }^{59}$

Finally, some listed SOEs may also resort to performance-based executive compensation as an additional method to align the company's management with the interests of private shareholders. Managers of SOEs are with recurring frequency not paid as bureaucrats on a fixed salary basis, but instead have their remuneration packages linked to different metrics of the company's performance. Either through stock grants, stock options, or bonus linked to the company's financial or operational results, these forms of incentive-based compensation can serve as a useful form of institutional tension to counterweigh managers' otherwise unbounded loyalty to the policy interests of the government officials that appointed them. Nevertheless, due to bureaucratic constraints or pressure from organized groups (e.g. unions of SOEs), the compensation packages of SOE managers tend to be low-powered compared to those of private firms.

\section{b. Cross-listings on foreign exchanges}

SOEs may also attempt to credibly commit themselves to honest management and minority shareholder protection by listing their shares on foreign exchanges. In his review of the large literature on cross-listings, Karolyi summarizes the two competing hypotheses to explain why companies choose to list their shares overseas. The market segmentation (and liquidity) hypothesis posits that regulatory and information costs hinder the flow of capital across borders, so cross-listings allow firms to amplify and diversify their investment base. The bonding hypothesis, by contrast, attributes the choice of cross-listing to the desire of foreign issuers - especially those coming from jurisdictions with weak institutional environments - to commit to the higher standards of governance and transparency practiced in the host jurisdiction. ${ }^{60}$

Proponents of the bonding hypothesis have presented different pieces of evidence in support of this theory. Foreign firms whose home legal systems are weak enjoy substantial premiums and a reduction in their cost of capital when they cross-list

\footnotetext{
${ }^{58}$ Luca Enriques, Henry Hansmann \& Reinier Kraakman, The Basic Governance Structure: Minority Shareholders and Non-Shareholder Constituencies 89 et seq., in THE ANATOMY OF CORPORATE LAW: A COMPARATIVE AND FunCTIONAL APPROACH (Reinier H. Kraakman \& Henry Hansmann eds., 2004) (noting that employee board representation is particularly common in state-owned corporations in the EU). Brazil enacted its first law mandating the presence of one labor representative on SOEs' boards in late 2010.

${ }^{59}$ See note 82 infra and accompanying text.

${ }^{60}$ G. Andrew Karolyi, Corporate Governance, Agency Problems and International Cross-Listings: A Defense of the Bonding Hypothesis, 13 EMERGING MARKETS REV. 516 (2012).
} 
their stock in U.S. exchanges (though not necessarily in other foreign exchanges, such as London). ${ }^{61}$ Skeptics have however provided countervailing findings that cast doubt on the plausibility of the bonding hypothesis, ranging from the observation that the premia associated with cross-listings have a short life, to the conclusion that other factors - such as the correlation with U.S. stock market indices - account for the boost in performance of foreign company stocks that trade in the United States. ${ }^{62}$

Attacks on the bonding hypothesis have also focused on the precise legal mechanisms that are meant to make the commitment to protect investors credible. In a study of Mexican firms cross-listed in the United States, Jordan Siegel showed that enforcement against violations by foreign firms is exceedingly weak, so the bonding hypothesis is best described as reflecting "reputational" rather than strictly legal bonding. ${ }^{63}$ More recent studies have reached divergent conclusions regarding the willingness of U.S. regulators to file enforcement actions against foreign firms. ${ }^{64}$

Although the promise of bonding to higher governance standards through crosslisting is unlikely to be bullet-proof, it does provide an extra layer of comfort to private investors of SOEs by raising the costs of engaging in abusive practices. SOEs may pursue cross-listings as a way to tie the hands of the controlling shareholder (i.e., the government), as abuses of minority shareholders could generate international scandal and, ultimately, lead to the sanction of de-listing. In fact, both access to foreign capital and foreign legal protections has led SOEs to pursue cross-listings with great enthusiasm. Studies show that government-controlled firms are far more likely to crosslist in the United States than are private firms from the same home jurisdiction. ${ }^{65}$

\footnotetext{
${ }^{61}$ For a sample of more recent works supporting the bonding hypothesis, see Craig Doidge et al., Why Are Foreign Firms Listed in the U.S. Worth More?, 71 J. FIN. ECON. 205 (2004) (showing that foreign companies that cross-list in the U.S. boast higher Tobin's q compared to matching companies from the same jurisdiction); Craig Doidge et al., Has New York Become Less Competitive than London in Global Markets? Evaluating Foreign Listing Choices Over Time, 91 J. FIN. Econ. 253 (2009) (finding that the Sarbanes-Oxley Act does not eliminate the U.S. cross-listing premium); Luzi Hail \& Christian Leuz, Cost of Capital Effects and Changes in Growth Expectations around U.S. Cross-Listings, 93 J. Fin. Econ. 428 (2009).

${ }^{62}$ See, e.g., Sergei Sarkissian \& Michael J. Schill, Are There Permanent Valuation Gains to Overseas Listing?, 22 REV. FIN. STUD. 371 (2009) (finds that the most of the valuation gains from overseas listings are not permanent); Kate Litvak, The Relationship among U.S. Securities Laws, Cross-Listing Premia, and Trading Volumes, http://papers.ssrn.com/sol3/papers.cfm?abstract_id=1443590 (unpublished working paper, 2009) (shows that valuations of foreign firms cross-listed on U.S. exchange are strongly correlated with U.S. stock indices).

${ }^{63}$ Jordan Siegel, Can Foreign Firms Bond Themselves Effectively by Renting U.S. Securities Laws?, 75 J. FIN. ECON. 319, 321 (2005).

${ }^{64}$ See, e.g., Natalya Shnitser, Note, A Free Pass for Foreign Firms? An Assessment of SEC and Private Enforcement Against Foreign Issuers, 119 YALE L.J. 1638 (2010) (describing the dearth of enforcement actions against foreign issuers). But see Roger Silvers, SEC Enforcement of Foreign Firms: Is Bonding Really a Myth? (unpublished working paper, 2012), http://business.illinois.edu/accountancy/events/forum/papers/11-12/Silvers.pdf (finding considerable enforcement intensity by the SEC against foreign issuers in the post-2002 period).

${ }^{65}$ Peter Alexis Gourevitch \& James J. Shinn, Political Power and Corporate Control: The NEW Global Politics of CORPORATE GOVERnANCE 114 (2005) (“[T]he percentage of U.S. cross-listers is weighted towards government-owned firms, to an extent far larger than the weight of state-controlled firms in their domestic stock markets”).
} 
Overseas listings may be particularly attractive for SOEs for their potential to eliminate the conflicts of interest stemming from the state's dual role as shareholder and regulator in domestic markets.

\section{Public law constraints}

\section{a. Public law rules}

Listed SOEs are not only generally subject to the same private and securities laws applicable to private firms, but also at times to constraints derived from public law as well. It is not uncommon for these hybrid public-private entities to be governed by a legal regime that blends elements of both public and private law. Defined by greater rigidity and formalities, public law rules have earned a bad reputation, especially when applied to commercial ventures. In fact, the desire to evade public law rules underlies the widespread "corporatizations" of government agencies. ${ }^{66}$ Yet, as we will see in Part III, the continued application of some public law constraints might well have beneficial properties with respect to listed SOEs. ${ }^{67}$

Well-designed public law rules have a comparative advantage with respect to their core competency: constraining state action. The private law regime is based on the general assumption that consensual transactions increase social welfare, hence granting the parties' substantial leeway to shape their actions and behavior. Public law, on the other hand, is imbued with greater suspicion about government action, and therefore seeks to impose limitations on the scope of state discretion. Frequently embodied in constitutional provisions or special statutes, public law rules are also harder to change, which makes them less susceptible both to efficient revisions and to opportunistic regime changes by the ruling government.

\section{b. Different regulatory agencies}

The institution of competing regulatory agencies to oversee SOEs is also a promising device to tame Leviathan in business. Inspired on the old wisdom of "pitting power against power," this is an adaptation of the most time-tested mechanism of controlling state abuse. The OECD Guidelines on Corporate Governance of SOEs specifically recommends the separation of the government agencies responsible for exercising the ownership function in government-controlled firms, on the one hand, and in regulating industry, on the other, so as to mitigate the potential conflict of interest.

\footnotetext{
${ }^{66}$ In 1934, U.S. President Franklin Delano Roosevelt exalted the creation of the Tennessee Valley Authority, a government corporation, as "a corporation clothed with the power of government but possessed of the flexibility and initiative of a private enterprise." From the New Deal to a New Century, http://www.tva.gov/abouttva/history.htm.

${ }^{67}$ See note _ infra and accompanying text.
} 


\section{Legal privileges}

Although questionable from a welfare standpoint, government ventures often enjoy an array of legal privileges that play an important part in explaining their ability to lure private shareholders. It is particularly common for governments to confer monopoly rights on the firms they control. Beyond an outright grant of monopoly, legal privileges can take different forms. SOEs may be the direct beneficiaries of special taxes or other government transfers that increase their revenue base. Moreover, it is customary for SOEs to be exempted from bankruptcy laws and to benefit from an implicit government guarantee. ${ }^{68}$ This can encourage private investors to lend to SOEs on favorable terms. A lower cost of debt, in turn, indirectly increases profitability, thus making the company more attractive to equity investors as well.

The point here is not to evaluate these privileges from a normative perspective. Standard recommendations customarily go against the grant of legal privileges or monopoly rights so as not to distort competition - for good and obvious reasons that do not merit extended discussion here. ${ }^{69}$ These favors, however, go a long way in explaining why private investors may voluntarily join sides with the state despite the apparent risks and conflicts of interest involved.

\section{Extralegal factors}

Finally, aside from legal constraints, there are several extralegal factors that entice investors to invest in SOEs.

\section{Market structure}

Although government ownership and monopolistic exploitation of industry are not inevitably intertwined, SOEs very often possess market power. This privileged position typically derives either from outright monopoly grants by the government or from industry characteristics - natural monopoly or "strategic" activities - that have called for the government's intervention in the first place. Monopoly rents, in turn, are evidently attractive to private investors. Even if the state has political objectives to fulfill, there should be sufficient money left on the table to provide for decent returns.

From a private shareholders' standpoint, the attractiveness of a monopolistic position may be easier to grasp, but the countervailing benefits of competition are not negligible. At the cost of eliminating rents, competitive market pressures are a source of discipline for managers of SOEs. In their review of the privatizations' literature, Megginson and Netter note that the effects of competition on SOE efficiency can be

\footnotetext{
${ }^{68}$ See CORPORATE GOVERnANCE OF STATE-OWNED EnTERPRISES: A SuRVEy OF OECD COUNTRIES 13, 56 (2005) ("in a number of cases, SOEs are to a large extent protected from insolvency or bankruptcy procedures by their specific legal status").

${ }^{69}$ OECD Guidelines, supra note 51.
} 
exceedingly strong even in the absence of ownership changes. ${ }^{70}$ Similarly, in a study of Indonesian firms, Bartel and Harrison find that SOEs facing competitive pressures perform as well as private firms. ${ }^{71}$ Competition, when available, eliminates rents but impose another form of constraint on state-owned firms. Large institutional investors that look for firms with good corporate governance in general, may prefer SOEs that operate in more competitive environments. Yet, investors may have higher returns in SOEs that operate in a monopoly setting, as long as corporate governance and reporting arrangements stemming from listing align the incentives of managers and minimize abuses of minority shareholder rights.

\section{Political and democratic control}

If SOEs face a greater risk of misbehavior compared to private firms, they also receive greater media and political scrutiny that can help deter abuse. Media pressure can be an effective remedy against private benefits of control, ${ }^{72}$ and listed SOEs are more frequently the object of media reports and congressional investigations than are private firms. This does not prevent public officials from using SOEs to pursue popular objectives, but at least reduces the risk of corruption and outright self-dealing.

\section{Reputation}

Reputation can be an effective substitute for legal protections in a repeat-play game. So long as the government has an interest in maintaining its mixed enterprise strategy, it must not expropriate current investors, as this will make it harder for the state to raise outside equity in the future. Even in the absence of formal legal protections, governments can resort to generous dividend policies in order to signal their commitment to stock profitability. ${ }^{73}$ The pervasive use of sovereign debt shows how, when coupled with internal checks-and-balances, ${ }^{74}$ reputational concerns can discourage defaults in a context where effective legal enforcement of contracts is not available.

\section{Investors' need to diversify their portfolio}

Beyond all the changes in governance in SOEs and the legal conditions that might make investment in the equity (or bonds) of a state-owned enterprise, investors

\footnotetext{
${ }^{70}$ William L. Megginson \& Jeffry Netter, From State to Market: A Survey of Empirical Studies on Privatizations, 39 J. ECON. LIT. 321, 332 (2001).

${ }^{71}$ Ann P. Bartel \& Ann E. Harrison, Ownership versus Environment: Disentangling the Sources of Public-Sector Inefficiency, 87 REV. ECON. \& STAT. 135, 137 (2005).

${ }^{72}$ Alexander Dyck \& Luigi Zingales, Private Benefits of Control: An International Comparison, $59 \mathrm{~J}$. Fin. 537, 590 (2004).

${ }^{73}$ Brian R. Cheffins, History and the Global Corporate Governance Revolution: The U.K. Perspective, 43 Bus. HIst. 87, 100 (2001) (arguing that U.K. companies in the first part of the twentieth century resorted to a stable record of dividend payments as a reputational device to reassure investors in the absence of other, more formal legal protections).

${ }^{74}$ Douglass C. North \& Barry R. Weingast, Constitutions and Commitment: The Evolution of Institutional Governing Public Choice in Seventeenth-Century England, 49 J. ECON. HIST. 803 (1989) (highlighting the role of internal checks-and-balances in ensuring England's access to capital markets following the Glorious Revolution).
} 
may also like to purchase the securities SOEs issue simply as part of the need to diversify their portfolio or to include exposure to a specific industry or country, or both. The sheer size of SOEs in many markets forces local and foreign investors who are looking to diversify their portfolio to invest in these firms. For instance, a foreign investor looking to diversify her portfolio by including Brazilian stocks may have to buy shares in SOEs because they represent $30-40 \%$ of stock market capitalization in the country. In China, firms ultimately controlled by the state or by a state-owned holding company (e.g., SASAC), represent close to $80 \%$ of stock market capitalization. ${ }^{75}$ An investor looking to include Chinese stocks in her portfolio will have, almost by force, to invest in SOEs. The same may happen with an investor that is trying to construct a diversified portfolio of energy firms. Since some of the largest firms worldwide are state-owned, these investors may have to include a mixed enterprise such as Petrobras, Statoil, Sinopec, CNOCC, or Gazprom. That is, it is very hard for investors to shy away from investing in SOEs. SOEs accounted for 9 out of the 15 largest initial public offerings between 2005 and 2012, and for the two or three largest offerings among them. ${ }^{76}$

\section{Ex ante discounting}

Last, when investors participate in SOEs voluntarily, they can and do adjust the price they are willing to pay for these securities to compensate for the risk that the government as controlling shareholder might pursue objectives that are not in their or the firm's best interests. Not only the presence of the government as a controlling shareholder is well known, but the public disclosure documents of listed SOEs describe the various risks associated with state control of the firm. ${ }^{77}$ It should come as no surprise that, among the world's 100 largest companies by mid-2012, the top four most “discounted” firms (measured by their price-to-book ratios) were SOEs. ${ }^{78}$

Discounting, however, may not work well if the extent and incidence of interference is too uncertain. This should be particularly relevant in moments of governmental transition involving political parties with distinct ideologies. Therefore, the very possibility of discounting as a response to the risk of political interference depends on the previously discussed legal and extralegal constraints on the government as a controlling shareholder.

\footnotetext{
${ }^{75}$ Aldo Musacchio and Sergio G. Lazzarini, Leviathan Evolving: New Varieties of State Capitalism in Brazil and Beyond, book manuscript, Harvard Business School, December 2012, Appendix 1-1.

${ }^{76}$ For the IPO list, see State capitalism's global reach: New masters of the universe. How state enterprise is spreading, THE ECONOMIST, Jan. 21, 2012.

${ }^{77}$ See notes 95 and 99 infra and accompanying text.

78 These firms were Japan's NTT, Japan Tobbaco, Russia's Gazprom and Brazil's Petrobras. Toni Sciarretta \& Álvaro Fagundes Petrobras é a petroleira mais desvalorizada [Petrobras is the most devalued oil company], FOLHA DE S. PAULO, Jun. 28, 2012.
} 


\section{Comparative Case Studies}

In light of our previous discussion, we now present some comparative cases studies on three national oil companies (NOCs): Brazil's Petrobras, Norway's Statoil and Mexico's Pemex. In Table 2 we include some basic corporate characteristics of two mixed, listed enterprises - Petrobras and Statoil - as well as of Pemex, a non-listed, wholly-owned instrumentality of the Mexican government, as a control case. These comparisons allow us to study the main differences between whole and mixed government ownership, as well as the variation in the governance structure and the level of political intervention among listed firms.

A quick look into the history of these NOCs reveals that state control of local companies emerged under different circumstances and for divergent reasons. The oldest among them, Pemex (short form for Petroleos Mexicanos) was created in 1938 as a result of the world's first large-scale nationalization in the oil industry. ${ }^{79}$ The full state takeover of the 17 foreign oil companies then operating in the country followed major labor revolts and the firms' subsequent refusal to follow court decisions siding with the employees. ${ }^{80}$ Although employee interests played a prominent part in Pemex's creation and continue to influence its governance, this very large SOE is best known for its national monopoly as well as its contribution to the government's finances. As of 2011, it accounted for over one-third of the revenues of the Mexican state, thus proportionately reducing the country's tax burden. As a wholly-owned instrumentality of the Mexican government, Pemex has private debt, but not equity, investors.

Brazil's Petrobras has been formally a mixed enterprise since the outset of its creation in 1953, even if the lion's share of its financing came directly from the state. Its founding followed a nationalistic campaign known as "the oil is ours" and great hopes to find promising oilfields along Brazil's shores to propel the country's economic and industrial development. Investment by (Brazilian) private shareholders was initially compulsory, deriving from a mandatory tax on automobile owners in exchange for shares. By the 1970s, Petrobras's stock was one of the most traded on Brazilian stock exchanges, but it was not until the 1990s that its monopoly was relaxed, the government floated a larger minority of its stake, and it began issuing ADRs on the NYSE.

Finally, Statoil was established as a wholly-owned SOE in 1972 with the goal of promoting the development of Norway's oil incipient industry, which also came to rely on private firms. The company was partly privatized in 2001, when minority stakes were successfully listed both on the Oslo Stock Exchange and on the NYSE. Statoil then merged with sister state-controlled oil firm Hydro in 2006 to become the world's biggest offshore operator.

\footnotetext{
${ }^{79}$ TORDO, TRACY \& ARFAA, supra note 11, at 17.

${ }_{80}$ History of $\quad$ Petroleos available at http://www.pemex.com/index.cfm?action=content\&sectionID=123\&catID=11682.
} 


\section{A. Ownership and governance}

\section{Board composition}

In Table 2, we show variation in degree of state ownership and control (the share of equity and votes held by the government) and in the levels of managerial autonomy conferred on the company (the extent to which the firm controls the use of its own resources independently of government approval). As noted above, Pemex is a nonlisted public enterprise that has since 2008 adopted most of the features of state-owned "corporatized" firms. Petrobras and Statoil, on the other hand, are state-controlled firms with shares listed in local exchanges as well as ADRs (American Depositary Receipts) traded on the New York Stock Exchange. Yet, at a glance, the makeup of all three boards of directors looks very similar: they are all relatively large and boast external members.

At Pemex, however, the only external members are full-time directors (an anomaly) appointed by the dominant political parties in Congress. As a result, the socalled "external" members of the board have in fact a direct connection to the government, which accentuates political intervention in the firm. Furthermore, government officials are among the non-external members of the boards of Petrobras and Pemex. In both of those firms external members make up a minority of directors, so the board is still heavily influenced by the government. Statoil is a unique case in which the board is composed by a majority of external members who are relatively independent from the government.

Indeed, Norwegian law has long barred the presence of government officials on Statoil's board of directors. In 1962, there was an accident in a state-owned mining company that had the Minister of Industry serving on the board. A political scandal ensued, blaming the accident on government negligence; the Labour government lost a confidence vote because of that. The solution was to prohibit public servants from serving on boards, so as to "[protect] politicians and government officials when stateowned ventures go bad., 81

Conversely, all three companies have employee representatives serving on their boards. At five board members selected by the Petroleum Workers' Union (Sindicato de Trajadores Petroleros de la República Mexicana), the degree of labor involvement in Pemex is substantial, perhaps as a vestige of employee revolts preceding the company's nationalization. In accordance with Norwegian law governing private firms, Statoil has three employee representatives on its board. At Petrobras, the presence of one labor representative on the board is far more modest and recent, dating back to a 2010 statute mandating the presence of an employee representatitive on boards of federal SOEs. Although the conflicts of interest between shareholders (who aim for maximum financial returns) and employees (who seek higher salaries) are well known, both

\footnotetext{
${ }^{81}$ Mark C. Thurber \& Benedicte Tangen Istad, Norway’s Evolving Champion: Statoil and the Politics of State Enterprise 28, Program on Energy and Sustainable Development, Stanford University, Working paper 20 (2010).
} 
groups share an interest in reducing political interference so as to maximize the firm's revenue. Indeed, the employee representative sitting on Petrobras's board of directors (Conselho de Administração) has come to openly criticized what he sees as excessive political interference in the firm's management to pursue policies that run counter to the interests of the company. ${ }^{82}$ Of the three NOCs examined, only Petrobras grants a minimum of two board seats to minority shareholders, as required under general Brazilian corporate law (However, as we describe in Part III.F below, the precise practical operation and effectiveness of this right has been recently challenged.)

Therefore, the composition of the boards of directors of Statoil and Petrobras differs sharply in their mix of public and private involvement, suggesting there is no silver bullet for reassuring investors that these state-owned companies will not fall prey of political intervention. In the Norwegian company, the government selects most directors, but none of them are state officials. In the Brazilian oil giant, by contrast, a majority of government officials interacts with elected representatives of employees and minority shareholders.

\section{Ownership structure}

The ownership structure of NOCs underscores the robust private interest in state-controlled firms. Despite the fact that in both Petrobras and Statoil the government has uncontested control over the firm by holding a majority of the voting stock, we see a large proportion of equity owned by minority investors. In Petrobras, private voting and nonvoting shareholders get a majority of the company's cash flow rights. In Statoil, minority shareholders have 33 percent of cash flow rights. Furthermore, Petrobras's charter, in accordance with Brazilian corporate law, allows minority shareholders to vote as a bloc and elect up to two of the external board members, if a greater number of seats is not available under cumulative voting.

Table 2. Corporate Governance in Petrobras, Statoil, and Pemex (July 2012)

\begin{tabular}{|c|c|c|c|}
\hline & Petrobras & Statoil & Pemex \\
\hline \multicolumn{4}{|l|}{ Corporate governance } \\
\hline $\begin{array}{l}\text { Is it chartered as a standalone } \\
\text { company? }\end{array}$ & Yes & Yes & No \\
\hline Listed on a local stock exchange & Yes (São Paulo) & Yes (Oslo) & No \\
\hline Cross-listed stock & Yes (NYSE) & Yes (NYSE) & No \\
\hline \multicolumn{4}{|l|}{ Board of directors (BOD) } \\
\hline Number of seats & 9 & 10 & 15 \\
\hline Number of external directors & 2 & 7 & 4 \\
\hline Number of employee representatives & 1 & 3 & 5 \\
\hline
\end{tabular}

${ }^{82}$ Representante dos trabalhadores na Petrobrás denuncia ingerência política [Labor representative in Petrobras denounces political interference], O ESTADO DE SÃO PAULO, Dec. 13, 2012, at http://economia.estadao.com.br/noticias/negocios-\%20industria,representante-dos-trabalhadores-napetrobras-denuncia-ingerencia-politica,138070,0.htm. 


\begin{tabular}{|c|c|c|c|}
\hline External directors are a majority? & No & Yes & No \\
\hline $\begin{array}{l}\text { Are there government officials on } \\
\text { BOD? }\end{array}$ & Yes & No & Yes \\
\hline \multicolumn{4}{|l|}{ Shareholder rights and gov't power } \\
\hline Dual-class shares (voting/nonvoting) & $\begin{array}{l}\text { Yes (voting shares } \\
\text { and nonvoting } \\
\text { preferred shares) }\end{array}$ & $\begin{array}{l}\text { One class (one- } \\
\text { share, one-vote) }\end{array}$ & Not applicable \\
\hline Share of votes held by government & $\begin{array}{c}50.2 \% \text { (gov't) }+8.2 \% \\
\text { (gov't owned } \\
\text { BNDESPAR) }\end{array}$ & $67 \%$ & $100 \%$ \\
\hline $\begin{array}{l}\text { Gov't cash flow rights (\% of total } \\
\text { equity) }\end{array}$ & $\begin{array}{c}28.70 \% \text { (gov't) }+ \\
15 \% \text { (gov’t owned } \\
\text { BNDESPAR) } \\
\end{array}$ & $67 \%$ & $100 \%$ \\
\hline $\begin{array}{l}\text { Do minority shareholders have the } \\
\text { right to elect board members? }\end{array}$ & $\begin{array}{l}\text { Yes, two (or greater } \\
\text { under cumulative } \\
\text { voting) } \\
\end{array}$ & No & Not applicable \\
\hline \multicolumn{4}{|l|}{ Returns to government } \\
\hline Taxes as a \% of profits (2011) & $\begin{array}{l}25.2 \% \text { net ( } 34 \% \\
\text { minus deductions) }\end{array}$ & $\begin{array}{l}28 \% \text { of profits } \\
\text { minus deductions } \\
\text { for exploration } \\
\text { and depreciation }\end{array}$ & $56.2 \%$ of profits \\
\hline Additional payments to government & Dividends & $\begin{array}{c}\text { Dividends } \\
\text { according to cash } \\
\text { flow rights }+ \text { a tax } \\
\text { of } 3 \% \text { on all } \\
\text { dividends } \\
\end{array}$ & $\begin{array}{l}\text { All additional } \\
\text { profits minus } \\
\text { deductions for } \\
\text { exploration and } \\
\text { depreciation } \\
\end{array}$ \\
\hline
\end{tabular}

Source: Compiled from the companies’ websites and from questionnaires sent to Pemex.

\section{Financial independence and time horizon}

We also show in the table the extent to which the governments of Brazil, Norway, and Mexico tax these firms and how much the government takes in the form of dividends. The fiscal regimes of Petrobras and Statoil seem extremely similar. The government takes between 25 and 28 percent in taxes and then gets dividends according to the cash-flow rights of its shares (28.7 percent in Petrobras and 67 percent in Statoil). In Mexico, the government takes all of Pemex's profits-about 56 percent in taxes and the rest in dividends - then gives Pemex back some deductions for depreciation and to pay for exploration projects. That means that in Mexico Pemex has to bargain with the government to get funds to pursue exploration and development, while in Petrobras and Statoil the management of the firm has more financial autonomy from the government and can use retained earnings to finance investment.

A key concern in NOCs is how financially independent the firm is from the government. As we saw in Table 2, Pemex entirely lacks the capacity to retain earnings to make investments. In Table 3 we analyze the financial independence of each of our three firms in regards to large investment decisions. We can see that only the Norwegian government seems to give its national oil company complete budgetary 
autonomy. Petrobras needs government approval for certain large investment projects, while Pemex needs approval for investment projects and for its whole budget. In fact, Pemex has an internal control office and, additionally, needs to run major budget changes through the Minister of Finance. Of the three, then, Pemex has the least flexibility when it comes to the use of the resources it generates.

Moreover, as we previously discussed, the issue of how SOEs compare to private firms in terms of investment time horizon and risk appetite remains controversial. On the one hand, advocates of state ownership view private capital markets as excessively focused on short-term gain, which could lead private companies to forego profitable but risky and patient investments in research and development. On the other hand, there is the risk that election cycles could render SOEs even more concerned with short-term results than their private counterparts.

We think financial autonomy, in fact, allows national oil companies to focus on long-term investments, while also isolating themselves from some of the short-term financial considerations of governments. In the case of Pemex, the Mexican government maximizes the extraction of rents in the short run, to boost its government budget, while giving up the possibility of spending more on research and development (R\&D) or exploration. In Petrobras and Statoil, their relative financial autonomy allows them to set aside funds to invest in long term projects, such as $\mathrm{R} \& \mathrm{D}$, or exploration. Therefore, while Pemex has invested, on average, between $\$ 1$ and $\$ 3$ billion dollars per year in the last five years, Petrobras has had capital expenditures of between $\$ 5$ and $\$ 40$ billion. In the same way, in 2011, Petrobras spent the most (US\$1.5 bi) and Pemex the least (US\$344 mi) in R\&D, with Statoil falling in between.

Yet, our case studies do not help us get a clear answer as to whether mixed enterprises in the oil industry focus on short-term results, as a response to investors, or on the maximization of oil rents in the long run for the majority shareholder (the government). It seems like the answer is somewhere in between. In the case of Petrobras and Statoil, given their large investment budgets, we think that at least we can say the management of these firms is not only preoccupied with short-term considerations. In Pemex, the government has privileged extraction of rents in the short run over the maximization of rents in the long run and production suffered a steep decline between 2004 and 2009 for lack of investment in exploration and development. ${ }^{83}$

\section{Management selection and compensation}

Since governments traditionally intervened in SOEs by nominating as managers either politicians or politically-connected individuals, one concern for investors of national oil companies is the issue of how the top management of such firms is selected. In Table 3, we show a series of variables of interest with which to compare these three

\footnotetext{
${ }^{84}$ Ministros e diretor da ANP vão prestar esclarecimentos no Senado [Ministries and ANP director will provide explanations to Senate], REVISTA ÉPOCA, Aug. 4, 2011.
} 
firms in terms of the selection process for their CEOs, their backgrounds, and whether their compensation packages are incentive-compatible.

In terms of management selection, we can see that Petrobras's and Statoil's CEOs are selected by the board of directors, while Pemex's CEO is directly appointed by the president of Mexico. In Petrobras, however, the board is packed with government officials and government-appointed members. Therefore, the appointment of the CEO, in practice, can be a highly political process, with the president of Brazil having ultimate fiat power when it comes to who runs Petrobras and how. Yet, when we code for the background of the CEOs of these three firms, we find that both Petrobras and Statoil have had far fewer politicians appointed as CEOs than Pemex. Moreover, at Pemex the CEOs change whenever a new president is elected, while in Statoil the terms seem to be more stable and long lasting. In Petrobras, CEOs have short tenures, but their appointment usually does not coincide with presidential elections.

A major source of concern for investors in SOEs is whether managers have incentives to improve the company's financial performance. In wholly-owned SOEs, CEOs usually have conflicting objectives that discourage them from running the firms profitably. Also, large SOEs are usually too big to fail and are commonly bailed out by governments when they face significant losses (i.e., CEOs of SOEs face a soft-budget constraint), which further compromises the incentives for financially responsible management. As we can see in Table 3, however, mixed enterprises such as Petrobras and Statoil have executive compensation packages that include "pay-for-performance" components. Statoil's CEO also owns a significant amount of shares in the company, thus further aligning his incentives with those of private stockholders.

One important way to minimize principal-agent problems in any firm is to have shareholders and other stakeholders (e.g., creditors) closely monitor the firm's management. Effective monitoring, in turn, presupposes a certain level of financial transparency with standardized quality. In state-owned enterprises that do not have private investors, the difficulty in monitoring by stakeholders is compounded by the fact that CEOs may not want to have good financials that allow the government to scrutinize their performance. Mixed enterprises such as Petrobras and Statoil, however, have facilitated the monitoring process by having audited financials that comply with International Financial Reporting Standards (IFRS), which are the standards set by the International Accounting Standards Board. In order to guarantee their quality, both firms hire internationally recognized accounting firms to audit their quarterly financials. Having such transparent financial reporting standards allows large institutional investors to more effectively monitor managers. In the case of Petrobras, Brazilian pension funds and Black Rock are the largest institutional investors monitoring management and acting as checks and balances on the controlling shareholder (i.e., the Brazilian government). In the case of Statoil, the Norwegian National Insurance Fund is the largest institutional investor. Additionally, these mixed enterprises issue debt in public markets and, thus, have international credit rating agencies such as S\&P and Moody's rate their local- and foreign-currency denominated debt. These rating agencies act as an 
additional gatekeeper, even though the implicit government guarantee enjoyed by some SOEs could decrease creditors’ incentives to monitor the firm closely.

All of these features are not exclusive of publicly-traded mixed enterprises, though. Pemex, a corporatized firm, issues debt in international markets and, therefore, has to comply with the same level of financial reporting that is required of Petrobras and Statoil.

Table 3. CEOs, Incentives, and Reporting in Petrobras, Statoil, and Pemex (July 2012)

\begin{tabular}{|c|c|c|c|}
\hline & Petrobras & Statoil & Pemex \\
\hline $\begin{array}{l}\frac{\text { CEOs/incentives }}{\text { Responsibility for CEO }} \\
\text { appointment }\end{array}$ & Board of directors & Board of directors & President of Mexico \\
\hline Current CEO & $\begin{array}{c}\text { Maria das Graças } \\
\text { Foster (technical CEO, } \\
\text { though with close ties } \\
\text { to President Dilma } \\
\text { Roussef) } \\
\end{array}$ & $\begin{array}{c}\text { Helge Lund } \\
\text { (technical-politician) }\end{array}$ & $\begin{array}{l}\text { Juan José Suárez } \\
\text { Coppel (technical) }\end{array}$ \\
\hline \multicolumn{4}{|l|}{ Background (1990-2012) } \\
\hline Number of CEOs & 10 & 6 & 9 \\
\hline $\begin{array}{l}\text { Number of CEOs with } \\
\text { technical background (even if } \\
\text { they were politicians)* }\end{array}$ & 10 & 4 & 6 \\
\hline $\begin{array}{l}\text { CEOs who were politicians } \\
\text { (\% of all CEOs) }\end{array}$ & $\begin{array}{c}1 \\
(10 \%)\end{array}$ & $\begin{array}{c}4 \\
(40 \%) \\
\end{array}$ & $\begin{array}{c}5 \\
(55 \%) \\
\end{array}$ \\
\hline Avg. CEO tenure in years & 2.7 & 6.7 & 3.2 \\
\hline $\begin{array}{l}\text { Do CEOs usually change after } \\
\text { presidential elections? }\end{array}$ & In 3 out of 7 elections & No & Yes \\
\hline $\begin{array}{l}\text { CEO compensation has pay- } \\
\text { for-performance component }\end{array}$ & Yes & Yes & No \\
\hline CEOs get stock options & No & Yes & No \\
\hline CEOs have shares & Yes & Yes & No \\
\hline \multicolumn{4}{|l|}{$\begin{array}{l}\text { Financial information and } \\
\text { transparency }\end{array}$} \\
\hline Autonomous budget & $\begin{array}{c}\text { No, some investments } \\
\text { need gov't approval }\end{array}$ & Yes & $\begin{array}{l}\text { No, some } \\
\text { investments need } \\
\text { gov't approval } \\
\end{array}$ \\
\hline $\begin{array}{l}\text { Audited financials (by a } \\
\text { private firm) }\end{array}$ & Yes & Yes & Yes \\
\hline Accounting standards & IFRS & IFRS & IFRS (since 2012) \\
\hline $\begin{array}{l}\text { Frequency of financial } \\
\text { reporting }\end{array}$ & Quarterly & Quarterly & Quarterly \\
\hline Main institutional investors & $\begin{array}{l}\text { Local pension funds, } \\
\text { Black Rock }\end{array}$ & $\begin{array}{l}\text { Norwegian national } \\
\text { insurance fund }\end{array}$ & $\begin{array}{l}\text { Bondholders \& Ex- } \\
\text { Im Bank }\end{array}$ \\
\hline
\end{tabular}




\begin{tabular}{|c|c|c|c|}
\hline $\begin{array}{l}\text { S\&P rating of long-term } \\
\text { domestic currency bonds }\end{array}$ & $\mathrm{BBB}$ & AA- & A- \\
\hline Regulation & $\begin{array}{l}\text { National Oil Agency } \\
\text { (ANP), linked to the } \\
\text { Ministry of Mines and } \\
\text { Energy }\end{array}$ & $\begin{array}{l}\text { Norwegian } \\
\text { Petroleum } \\
\text { Directorate (NPD), } \\
\text { reporting to the } \\
\text { Ministry of } \\
\text { Petroleum and } \\
\text { Energy }\end{array}$ & $\begin{array}{l}\text { National } \\
\text { Carbohydrates } \\
\text { Commission (CNH } \\
\text { in Spanish), a } \\
\text { decentralized agency } \\
\text { linked to the } \\
\text { Ministry of Energy } \\
\text { (SENER) }\end{array}$ \\
\hline
\end{tabular}

Source: Compiled from the companies’ websites and from questionnaires sent to Pemex.

Note: IFRS stands for International Financial Reporting Standards, which are the standards set by the International Accounting Standards Board. IFRS usually requires companies to disclose more detailed accounts than the GenerallyAccepted Accounting Principles (GAAP), which are the required accounting standards to list shares or trade bonds on the New York Stock Exchange.

*We code CEOs as having a technical background if they studied engineering, economics, business or geology or had a career in the oil industry before running for a political post or being appointed for a cabinet position.

\section{B. Regulation and market structure}

\section{Industry regulation}

All three NOCs are subject to supervision by established regulatory agencies that report to governmental bodies (such as Ministries of Energy) and are, at least on paper, run by technical professionals. However, a deeper inspection of the roles of those agencies reveals profound differences. Brazil's National Oil Agency (ANP), which was created in 1997 as a counterweight to the end of Petrobras's legal monopoly, is still relatively weak and heavily influenced by the executive. Furthermore, it has had a stained reputation since ANP officials were caught requesting bribes from private companies. ${ }^{84}$ As a consequence, the president of Brazil and the Minister of Mines and Energy are the most important "regulators" of Petrobras.

In Mexico, the government passed a law in 2008 creating the National Carbohydrates Commission (Comisión Nacional de Hidrocarburos - $\mathrm{CNH}$ ). It was intended to be an autonomous agency run by commissioners with technical knowledge of the sector. In practice, however, the commissioners were not experts - at least, not all of them-and they have had some differences with Pemex. Moreover, the de facto regulator of Pemex's actions is the Ministry of Finance, which controls the budget of Pemex (line by line) and whose minister serves as chairman of Pemex’s board.

In contrast to the Mexican and Brazilian cases, the Norwegian Petroleum Directorate (NPD), although also subordinate to the Ministry, is functionally

\footnotetext{
${ }^{84}$ Ministros e diretor da ANP vão prestar esclarecimentos no Senado [Ministries and ANP director will provide explanations to Senate], REVISTA ÉPOCA, Aug. 4, 2011.
} 
autonomous and strong. It has a longer history, as it was instituted in 1972 to regulate Norway's public and private actors in the oil industry. As put by Thurber and Istad: ${ }^{85}$

Since the Norwegian Petroleum Directorate formally reported to the Ministry, it was initially felt necessary to have an independent board oversee the directorate to guarantee its independence from politics. In time, however, this board was judged to be superfluous, and in 1991 it was disbanded... What ultimately protected the NPD from undue interference was the growing dependence of the Ministry on it for critical technical services and advice. (One early Ministry official said that the NPD tended to be viewed within the Ministry as its own technical department.) Any actions that would have severely disrupted this function would have been detrimental to both organizations.

The existence of an autonomous regulatory agency thus helped create institutional checks and balances that reduced the government's ability to directly intervene in the company. And, in the case of NPD, such autonomy was apparently due to the presence of technical regulators with distinct knowledge and capabilities.

\section{Labor laws}

Labor laws illustrate how the precise combination between public and private elements in mixed enterprises can vary widely depending on the institutional context At one end of the spectrum, Norway imposes on Statoil precisely the same laws applicable to private companies regarding the commercial contracting process, employee recruitment and labor matters. By contrast, the legal regime applicable to Brazil's Petrobras is markedly hybrid. Its employees are subject to the same labor laws governing private firms - the labor-friendly Consolidação das Leis do Trabalho $C L T{ }^{86}$ Unlike public servants in Brazil, Petrobras's employees do not have tenure and can be fired at will. ${ }^{87}$ Differently from private companies, however, Petrobras must generally abide by a distinct process for employee recruitment through a constitutionally mandated public contest of examinations and titles. ${ }^{88}$

The fusion of public and private law regimes, in this case, serves to mitigate the disadvantages of each in the peculiar SOE context. While ample leeway for hiring and firing decisions is generally thought to be most efficient for private companies, there is the risk that, in a government-controlled firm, this regime might lead to staffing decisions being made according to political alliances, ideology or cronyism rather than merit and technical considerations. Although public examinations measure soft skills imperfectly, they favor the recruitment of a technically-qualified labor force. At the same time, the ability to dismiss underperforming employees mitigates incentives problems.

\footnotetext{
85 Thurber \& Istad, supra note 81, at 28.

${ }^{86}$ Constitution of the Federative Republic of Brazil, art. 173, $\S 1^{\circ}$.

${ }^{87}$ Súmula of Tribunal Superior do Trabalho [Statement by the Superior Labor Court] 390, II.

${ }^{88}$ Constitution of the Federative Republic of Brazil, art. 37, II.
} 


\section{Market structure}

There are also important differences in terms of market competition. For most of its history, Petrobras had a legal monopoly on research, extraction, refining, and transportation. Even though a 1995 constitutional amendment permitted the federal government to grant oil exploration rights to private firms pursuant to concession agreements, thus opening up the possibility of competition, Petrobras continues to enjoy a de facto monopoly, similarly to Pemex. It is hardly surprising that monopoly rents can look particularly attractive to private investors. Statoil, in contrast, was subject to domestic and foreign competition throughout its history. Although its merger with domestic rival Hydro in 2007 created a position of near monopoly in the domestic market, Statoil has been exposed to a number of foreign competitors given its more aggressive strategy of international expansion. ${ }^{89}$

\section{Financial performance}

As discussed in Part I, the promise of improvements in operational efficiency and performance is a main driving force behind minority private ownership in SOEs. According to this view, listed SOEs should boast financial results that are superior to those of wholly-owned state ventures. Based on our sample, we should expect Pemex to underperform both Petrobras and Statoil from a financial standpoint.

To see if this expectation holds, we collected financial data on the three companies from 1998 to 2011. We also split this window into two subperiods, 19982002 and 2003-2011, given that after 2002 oil prices sharply increased. Consistent with the original prediction, we find that Petrobras and Statoil are profitable, while Pemex reports losses in all periods. The return on assets (net profit to total assets) of Statoil, Petrobras and Pemex were on average 8\%, 11\% and -4\% respectively in 1998-2011. This lends support for the view that the institutional arrangements associated with mixed ownership create higher commitment towards superior profitability. Nevertheless, we do not find substantial differences in terms of the other accounting indicators except for the current liquidity ratio: although still liquid, Statoil exhibited a lower ratio than the other NOCs, especially after 2003.

For our purposes, however, the greater puzzle is why private investors are willing to join forces with the government as a controlling shareholder. Assuming that private shareholders are rational, their voluntary presence in SOEs suggests that these firms can indeed provide profitable investment opportunities. We would expect listed SOEs to post mostly positive financial results - as they indeed do. Theory alone, however, cannot determine if the interest of private investors is primarily due to (i) countervailing advantages of mixed enterprises (e.g., due to governmental privileges), (ii) ex ante discounting by investors, so that, in order to account for the risk of political intervention, their stock prices become inordinately cheap, or (iii) governance and legal mechanisms that mitigate agency costs, making listed SOEs behave similarly to private sector firms.

\footnotetext{
${ }^{89}$ Thurber \& Istad, supra note 81.
} 
A more direct comparison between Petrobras and Statoil shows that Statoil has underperformed Petrobras in terms of return of assets. On the other hand, Statoil's Tobin's q (market value of stock plus debt divided to total assets) and especially its price-to-book ratio are higher than Petrobras's. This finding suggests that improved governance and checks-and-balances against political interference in Statoil, compared to Petrobras, has resulted in superior market valuation, even considering Statoil's slightly lower profitability. In other words, investors might require greater financial returns and offer steeper discounts in order to invest in a state-owned enterprise that is more vulnerable to political interference.

It is also interesting to examine how the share prices of Petrobras and Statoil fared compared to those of private international oil companies (IOCs). Figure 1 shows the evolution of share prices departing from June 2001. The advantage of this temporal window is that it covers the marked increase in oil prices after 2003 and hence allows us to assess the impact of changing market conditions on the relative market evolution of share prices. Our previous discussion on ex ante discounting suggests that the share prices of SOEs, compared to IOCs, might be relatively less responsive to a thriving oil market because increases in perceived rents are constrained or captured by local governments, which are their majority shareholders.

Figure 1, however, indicates an opposite pattern. Share prices of Petrobras and Statoil escalated at a much higher pace than the share prices of private IOCs. In the case of Petrobras, this finding can be partially explained by the announced discovery of new pre-salt (deep-water) oil fields in Brazil in 2007, which illustrates how a privileged relationship with the government can also be a significant boon at certain times. ${ }^{90}$

However, we also see in Figure 1 that the share prices of Petrobras rapidly declined after 2009, and eventually fell below Statoil's prices after 2012. This is likely a result of escalating governmental interference at Petrobras, as discussed earlier, as well as delays in the exploitation of the newly discovered pre-salt oil fields.

Table 4. Financial Comparison of Petrobras, Statoil, and Pemex (millions of dollars)

\begin{tabular}{|c|c|c|c|c|c|c|c|c|c|}
\hline & \multicolumn{3}{|c|}{$1998-2011$} & \multicolumn{3}{|c|}{ 1998-2002 } & \multicolumn{3}{|c|}{ 2003-2011 } \\
\hline & Petrobras & Pemex & Statoil & Petrobras & Pemex & Statoil & Petrobras & Pemex & Statoil \\
\hline \multicolumn{10}{|l|}{ Financial data } \\
\hline Revenues & 62,156 & 76,895 & 57,360 & 21,683 & 45,209 & 22,816 & 84,640 & 90,977 & 76,551 \\
\hline Net profit & 9,810 & $-3,425$ & 4,447 & 2,944 & $-1,932$ & 1,295 & 13,624 & $-4,089$ & 6,197 \\
\hline Total debt & 53,671 & 17,845 & 36,630 & 19,129 & 15,947 & 16,642 & 72,862 & 18,688 & 47,735 \\
\hline Current assets & 26,670 & 22,124 & 14,543 & 10,406 & 10,247 & 6,371 & 35,706 & 27,402 & 19,083 \\
\hline Current liabilities & 18,780 & 14,493 & 13,892 & 9,386 & 9,439 & 6,475 & 23,999 & 16,739 & 18,013 \\
\hline
\end{tabular}

\footnotetext{
${ }^{90}$ The Brazilian government did not hesitate to transfer the exploration rights in the new oilfields to Petrobras, rather than auctioning them off to interested private oil companies (even though, as we will see in Part III.D below, the particular purchase price was challenged by investors).
} 


\begin{tabular}{lrrrrrrrrr} 
Total assets & 109,100 & 89,141 & 56,592 & 31,803 & 60,516 & 23,365 & 152,043 & 101,863 & 75,051 \\
Fixed assets & 62,631 & 59,866 & 32,928 & 12,576 & 41,894 & 14,137 & 90,440 & 67,854 & 43,368 \\
$\begin{array}{l}\text { Shareholders' equity } \\
\text { Accounting ratios }\end{array}$ & 55,429 & 3,290 & 19,962 & 12,674 & 13,959 & 6,723 & 79,182 & $-1,452$ & 27,317 \\
$\begin{array}{l}\text { Liquidity ratio (current } \\
\text { assets/current liabilities) }\end{array}$ & 1.33 & 1.53 & 1.02 & 1.11 & 1.09 & 0.99 & 1.45 & 1.64 & 1.05 \\
$\begin{array}{l}\text { Leverage (total } \\
\text { debt/total assets) }\end{array}$ & 0.26 & 0.20 & 0.18 & 0.29 & 0.26 & 0.23 & 0.24 & 0.18 & 0.15 \\
$\begin{array}{l}\text { Fixed investment (fixed } \\
\text { assets/total assets) }\end{array}$ & 0.52 & 0.67 & 0.60 & 0.40 & 0.69 & 0.61 & 0.59 & 0.67 & 0.59 \\
$\begin{array}{l}\text { ROA (net profit/assets) } \\
\text { Market indicators }\end{array}$ & 0.11 & -0.04 & 0.08 & 0.09 & -0.03 & 0.06 & 0.12 & -0.04 & 0.09 \\
Price-to-book ratio* & 1.82 & n.a. & 2.40 & 1.78 & n.a. & 2.40 & 1.84 & n.a. & 2.40 \\
$\begin{array}{l}\text { Tobin’s q* } \\
\text { Dividend yield* }\end{array}$ & 1.37 & n.a. & 1.48 & 1.24 & n.a. & 1.37 & 1.45 & n.a. & 1.50 \\
\hline Source: Bloomen & 4.19 & n.a. & 3.88 & 4.83 & n.a. & 4.54 & 3.84 & n.a. & 3.73 \\
\hline
\end{tabular}

Source: Bloomberg and Pemex, our calculations.

* Statoil's market indicators begin in 2001, when the company became listed. Pemex is nonlisted.

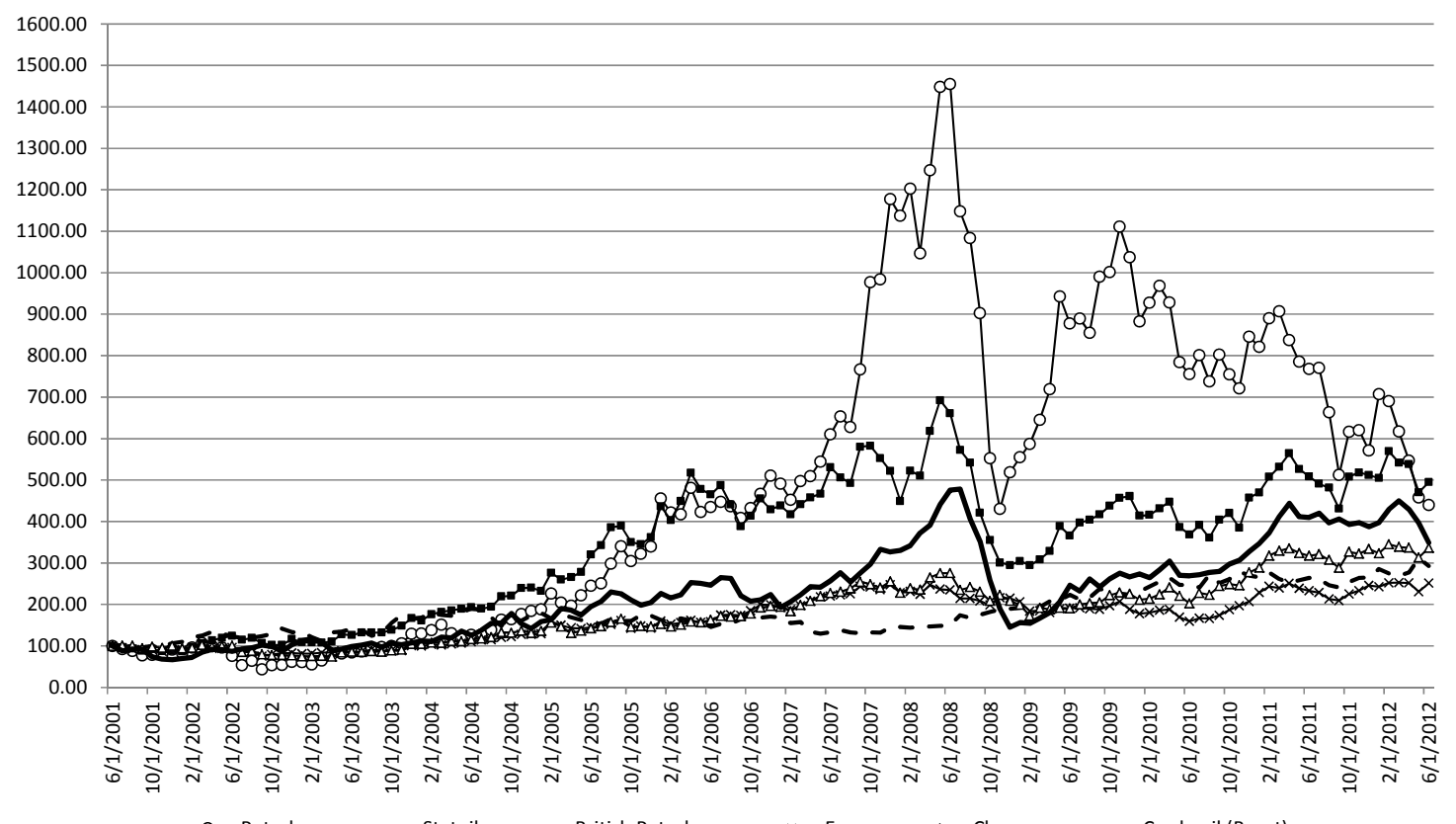

Figure 1. Evolution of Share Prices of Selected NOCs

Source: Bloomberg. Crude oil prices refer to Brent quotes.

\section{Evidence of remaining political interference}

While our case studies cannot fully discern whether countervailing advantages of SOEs or ex ante discounting can best explain private investment in listed SOEs, one aspect remains clear: while helpful, the corporate governance features of mixed 
enterprises that seek to isolate them from political intervention are not fully effective. Petrobras has not managed to shield itself from political intervention, despite its listing in New York (through American Depository Receipts) and São Paulo, as well as the technical nature of its management. Consider the case of the public offer of Petrobras' shares in 2010. On June 22, 2010, the board of directors of Petrobras approved an ambitious capital expenditure plan of \$224 billion for 2011 to 2014, including expenditures to explore and develop the pre-salt oil fields off the coast of São Paulo. Foreseeing expenditures on the order of $\$ 45$ billion per year for at least five yearsmore than Petrobras's cash flows could cover - the company decided to issue a mix of debt and equity. In fact, the company planned what might have been the largest public offer in the world, with the sale of shares totaling $\$ 50$ billion. $^{91}$ The share issue, in and of itself, was a major accomplishment for any corporation, involving six investment banks acting as global coordinators and nine as joint managers. ${ }^{92}$

The Brazilian government, the controlling shareholder of Petrobras, did not want to come across to the Brazilian public as selling its exploration rights to Petrobras too cheaply, especially since it was a presidential election year. Technically Petrobras would pay $\$ 42.5$ billion to the government for those rights - a price which was set by the government without consultation with (and under protests by) minority shareholders. Therefore, as Petrobras sold new shares, the government sold to Petrobras the rights to extract five billion barrels of oil at the equivalent price of $\$ 8.51$ per barrel in a transaction which was carefully designed to evade minority approval requirements under Brazil's corporate law for stock subscriptions that are payable in kind. Due to insufficient investor interest for the huge offering, the government decided to use those proceeds to purchase new shares, thus increasing its ownership stake in the company. Minority shareholders in Petrobras worried about this transaction. Of particular concern was the allegedly too high price paid for the exploration rights, the resulting dilution of minority shareholders who did not exercise their preemptive rights, the fact that exploitation rights were negotiated without consultation with minority shareholders and were paid for before they were going to be used. ${ }^{93}$

Moreover, in line with the social view of SOEs discussed earlier, Petrobras clearly follows a double bottom line. Brazil's constitution requires congressional approval of the annual budgets of SOEs, even if they do not presently receive capital infusions from the government and operate as autonomous entities. ${ }^{94}$ The company's securities filings warn that "[t]he Brazilian federal government, as our controlling

\footnotetext{
${ }^{91}$ Pargendler, The Unintended Consequences of State Ownership, supra note 52.

92 The details of the transaction are publicly known in Brazil. Rob Dwyer, How Petrobras Struck \$70 Billion, EuROMONEY, Mar. 2011.

${ }^{93}$ These complaints notwithstanding, the governmental abuse (if any) in fixing allegedly too high a purchase price was probably less serious than it could have been. Pargendler, supra note 31, at 2942. Reputation likely played a key role: too serious an instance of minority abuse could have jeopardized the government's plans to raise billions of dollars in a contemporary stock offering by Petrobras to fund the necessary investments in exploration of the oilfields. Some of these arguments came out in the press, but we also heard some of them from one of the most influential minority investors, who preferred to remain anonymous.

${ }^{94}$ Constitution of the Federative Republic of Brazil, art. 165, § 5 ${ }^{\circ}$, II.
} 
shareholder, may cause us to pursue certain macroeconomic and social objectives that may have a material adverse effect on us", including meeting "Brazilian consumption requirements" and setting prices for crude oil and oil products "below prices prevailing in world markets."95

For instance, the price of gasoline had been controlled in Brazil for years, but direct intervention in the management of the company mounted in early 2012. The appointment of Graça Foster as CEO of Petrobras in February 2012 was well received by market participants, due to her technical background; she had had a long career at the firm and was considered very knowledgeable about the sector. Graça Foster recognized that keeping gasoline prices low would undermine profitability and deteriorate the cash flow necessary to support future investments. At the time of her appointment, she gave an interview declaring:

If you ask me, is it necessary to adjust the price [of gasoline]? It is evident that it is necessary to adjust the price... It is not sensible to imagine that someone who sells anything — anything at all, a cup, a notepad, gasoline, diesel—should not transfer to the market his or her advantages or disadvantages. ${ }^{96}$

President Dilma Roussef and her Minister of Energy, however, publicly disavowed Graça Foster's statement and said that the price of gasoline would not be raised. They were both concerned that an increase in gasoline prices would accelerate inflation at a moment when the government was trying to force reductions in interest rates. In June 2012, the government allowed a minor adjustment-not enough to compensate for the large increases in the price of oil (at that moment trading close to $\$ 100$ per barrel). These price controls directly affect the profitability of Petrobras's refining division.

In May 2012, a group of foreign investors sent a letter to Graça Foster, criticizing the company's investment plan-approved by the board of directors — which would invest heavily in refining despite there being no clear plan to lift price controls for gasoline. Echoing these investors' concerns, Petrobras announced a record loss of $\$ 1,34$ billion reais (around $\$ 662$ million dollars) in the second quarter of 2012, its first loss in 13 years. Even if the loss was related to the write-off of a failed exploration attempt offshore, having the price of gasoline capped by the government certainly did not help profitability at Petrobras.

Investors also complained that the two board seats that the charter of Petrobras (and Brazilian corporate law) guarantees for minority shareholders were not really representing minority shareholders. ${ }^{97}$ These complaints echoed the concerns of

\footnotetext{
${ }^{95}$ Petrobras Form 20-F Annual Report pursuant to Section 13 or 15(d) of the Securities Exchange Act of 1934 for the fiscal year ended December 31, 2011.

${ }^{96}$ Graça defende correção do preço dos combustíveis [Graça defends adjustment to fuel prices], AGÊNCIA ESTADO, Feb. 27, 2012.

${ }^{97}$ Renato Rostás, Estrangeiros criticam eleição de conselho e plano da Petrobras [Foreigners criticize board election and plan of Petrobras], VALOR ECONÔMICO, Sept. 5, 2012.
} 
institutional investors Polo Capital and Black Rock, as the candidates they had nominated for the board had been defeated. The winners, Jorge Gerdau Johannpeter and Josué Gomes da Silva, were seen by these institutional investors as too close to the government: the former was a steel industrialist regularly consulted by Presidents Lula and Roussef and the latter, also a businessman, was the son of Lula's vice president. They were elected by the pension funds of two SOEs - the banks Banco do Brasil and Caixa Econômica Federal-and by BNDESPAR, the investment arm of Brazil's national development bank. The Securities and Exchange Commission of Brazil supposedly investigated the incident, but without major consequences.

In addition, Petrobras has procurement policies that force its suppliers to have a high national content. Those policies are of interest to the government, the controlling shareholder; they promote local investment and employment. But they are equivalent to an expropriation of minority shareholders, as national suppliers that are acquiring capabilities may be slower or more expensive, which of course can affect the firm's profitability. Last but not least, government interference can also occur to support geopolitical projects. In 2005, for example, Petrobras signed up for a joint venture with the Venezuelan oil company PDVSA to build a refinery in the Brazilian state of Pernambuco. This was a pet project of President Lula, a supporter of Hugo Chávez's regime in Venezuela. Petrobras originally projected costs to be around $\$ 2.3$ billion, but by 2012 , the costs were expected to be $\$ 20$ billion. $^{98}$

Such instances of outright interference are arguably much less frequent at Statoil. Yet, it is questionable how much political independence Statoil has in practice. Also suggesting the pursuit of political objectives, Statoil lists government control as a risk factor by noting that " $[t]$ he interests of our majority shareholder, the State, may not always be aligned with the interests of our other shareholders, and this may affect our decisions..." and Energy in Statoil strategy has mostly disappeared, politicians continue to weigh in as though they were making policy for the company." ${ }^{100}$ Two examples illustrate the prevalence of political intervention at Statoil. First, in October 2007, the government halted further developments of natural gas in the Troll field in Norway "on the grounds that such activity would likely harm the ultimate oil recovery from the field...Statoil was highly displeased based on commercial considerations." 101 Second, in April 2008, the Norwegian government filed a suit against Statoil for fees owed by the company for the expansion of a gas-processing terminal. "As one Ministry official explained, Statoil managers need to be diligent about not giving minority shareholders the impression they are paying off their main shareholder." ${ }^{102}$

\footnotetext{
${ }^{98} \mathrm{O}$ longo e pedregoso caminho que Graça Foster começou a trilhar [The long and difficult way of Graça Foster], VALOR ECONÔMICO, July 20, 2012.

${ }^{99}$ Statoil Form 20-F Annual Report pursuant to Section 13 or 15(d) of the Securities Exchange Act of 1934 for the fiscal year ended December 31, 2011.

100 Thurber \& Istad, supra note 81, at 9.

${ }^{101}$ Id. at 33.

102 Id. at 34 .
} 
Not surprisingly, even more acute such issues are now confronting the Mexican government, the sole owner of Pemex. On the one hand the Mexican government is planning to reform the company and possibly list in Mexico and abroad. The aim of the plan is to restructure corporate governance in a way that gives the firm more financial autonomy to pursue partnerships with foreign firms for deep water exploration. On the other hand, it is not clear the Mexican government can commit to keeping its hands off the cash flow of Pemex. Pemex has for decades been the cash cow of the Mexican government, providing almost $40 \%$ of the total revenues (up to $70 \%$ before the 1990 s). Additionally, the Mexican government controls gas, gasoline, and lubricant prices in a way that hurts the profitability of the firm. Moreover, the total take of the government in the form of taxes and dividends leaves the firm with little in the form of retained earnings to pay for new exploration, $R \& D$, and expansion. Thus, the planned reforms would leave the government with less money in the short rune, but without a change in the tax regime of Pemex, it would be hard for private investors to be interested in buying shares if it were to be privatized.

\section{Conclusion}

In this Article, we addressed the puzzle of mixed enterprise. How can we explain the very existence of these firms? Why do private investors agree to be minority shareholders in companies controlled by governmental entities with objectives that may drastically differ from profit maximization?

From the perspective of a social planner, there is evidence that the coexistence of minority private investors with state actors can generate improvements in operational and financial performance. Yet, from the perspective of private shareholders, their investment must pay off. We identified three different factors that explain private investor interest: the existence of countervailing privileges from partnering with the government, the resort to improved corporate governance and legal constraints that limit the opportunity for political abuse, and ex ante price discounting.

An important conclusion is that neither the very presence of private investors nor the listing of stock on a major stock exchange solves in and by itself the political intervention problem. Carefully-designed governance provisions can mitigate, but not eliminate, the degree of political interference to the detriment of minority investors. Because distinct governments may change governance rules at their discretion, it is also critically important to have a structure of institutional checks-and-balances in place. The case of Statoil, for instance, suggests that the presence of a technical, independent regulatory agency, with equal influence on private and state-owned firms, can reduce the level of outright interference by the government. Consequently, the discount applied by private investors may be reduced as well.

Our limited evidence seems inconsistent with the "discounting" hypothesis. The stock prices of SOEs actually increased to a greater extent than in the case of private oil companies. Indeed, to the extent that the degree and direction of political interference is 
difficult to anticipate, ex ante price discounting by private investors will be imperfect at best. Changing patterns of political interference at Petrobras clearly illustrate this point.

Yet private investors may be willing to accept these risks that remain after all legal and extralegal constraints to state abuse are taken into account. This is because SOEs may offer countervailing advantages, bringing a substantial stream of rents from the (often monopolistic) exploitation of natural resources and public concessions. These features may be highly attractive to fund managers and individual investors. In our analysis, we observed that the stock prices of SOEs actually increased to a greater extent than in the case of private NOCs when oil prices peaked. As another example, a report issued by Morgan Stanley in May 2012 argued that although SOEs may be "targeting development objectives rather than shareholder returns," several SOEs have outperformed industry peers in emerging markets. ${ }^{103}$

We do not purport to offer a definitive answer to the puzzle of private investment in SOEs, and much less to suggest that such an answer is likely to be uniform. Mixed corporations with state-control and private minority investments remain an under-researched phenomenon. The case-based empirical analysis presented here could be expanded by including more SOEs in alternative sectors. Scholars could, for instance, identify moments of market and political change and examine how different SOEs react to those changes, as a function of their governance profile and the institutional environment of their home country. We hope that our Article will help spark more research to improve our understanding of why mixed corporations exist and in which conditions they can become efficient organizational forms.

${ }^{103}$ Morgan Stanley, "EEMEA \& Latam Equity Strategy: State Controlled Companies - Where to Invest Now,” May 24, 2012. 